DOE/ID-22174

\title{
GEOCHEMISTRY OF THE BIG LOST RIVER DRAINAGE BASIN, IDAHO
}

U.S. GEOLOGICAL SURVEY

WATER-RESOURCES INVESTIGATIONS REPORT 01-4031

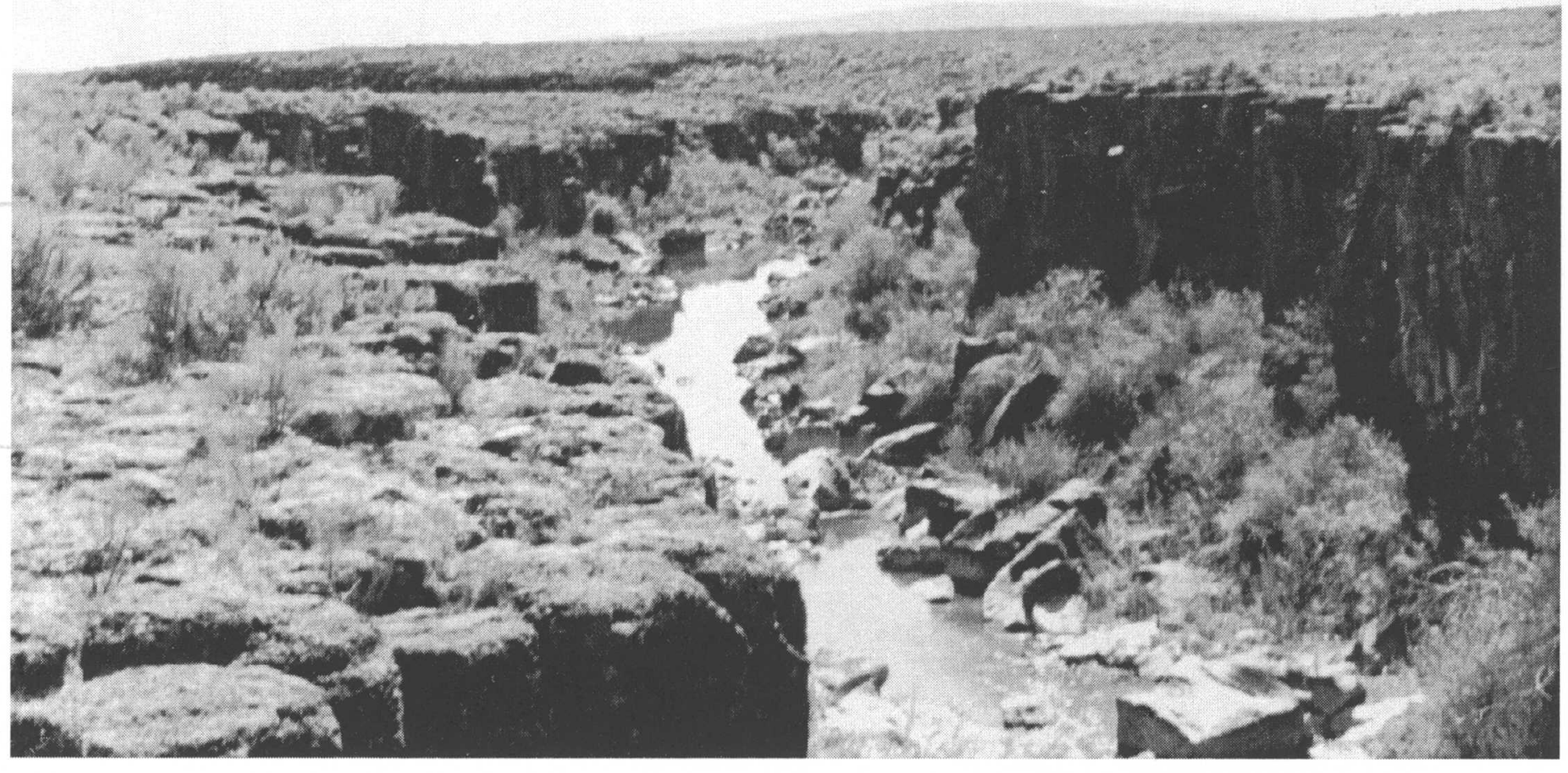

Prepared in cooperation with the U.S. DEPARTMENT OF ENERGY

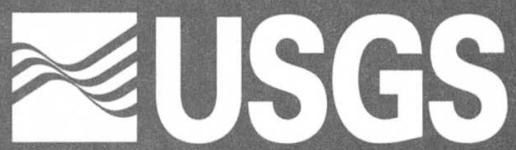




\section{GEOCHEMISTRY OF THE BIG LOST RIVER DRAINAGE BASIN, IDAHO}

By Colleen Carkeet, Jeffrey J. Rosentreter, Roy C. Bartholomay, and LeRoy L. Knobel

\section{U.S. GEOLOGICAL SURVEY}

Water-Resources Investigations Report 01-4031

Prepared in cooperation with the U.S. DEPARTMENT OF ENERGY

Idaho Falls, Idaho

January 2001 


\title{
U.S. DEPARTMENT OF THE INTERIOR \\ GALE A. NORTON, Secretary
}

\author{
U.S. GEOLOGICAL SURVEY \\ CHARLES G. GROAT, Director
}

Any use of trade, product, or firm names in this publication is for descriptive purposes only and does not constitute endorsement by the U.S. Government.

For additional information write to:

U.S. Geological Survey

INEEL, MS 1160

P.O. Box 2230

Idaho Falls, ID 83403
Copies of this report can be purchased from:

U.S. Geological Survey

Information Services

Box 25286, Federal Center

Denver, CO 80225 


\section{CONTENTS}

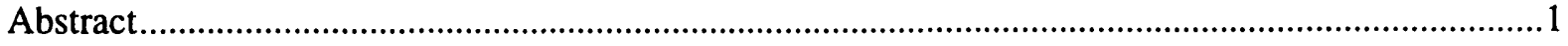

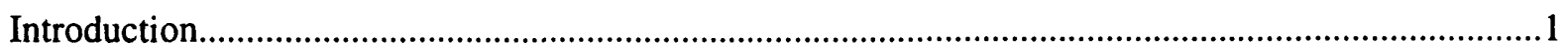

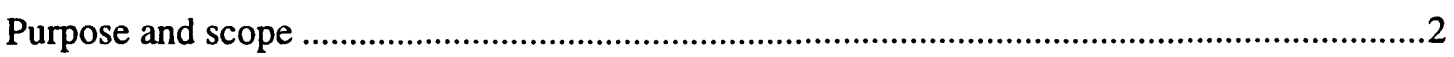

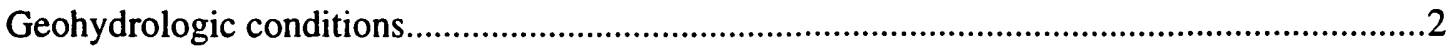

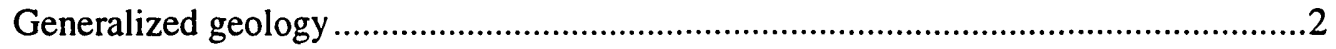

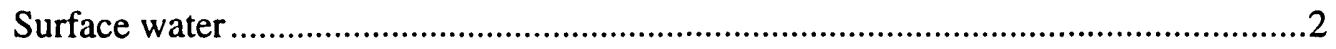

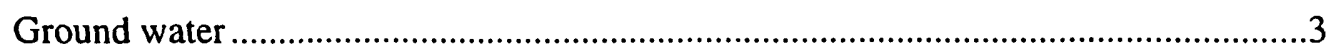

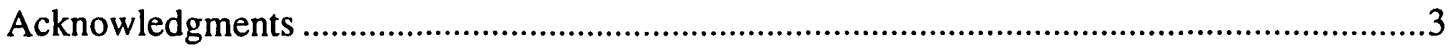

Guidelines, methods, and quality assurance ................................................................................

Sample containers and preservatives .......................................................................................

Sampling locations and sample collection............................................................................

Guidelines for interpreting results of analyses ...................................................................

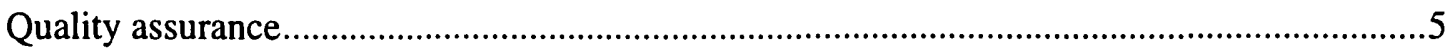

Evaluation of quality assurance data .............................................................................................

Inorganic constituents ........................................................................................................6

Dissolved organic carbon ……………………………………………………………...6

Radiochemical analyses and stable isotopes ..................................................................6

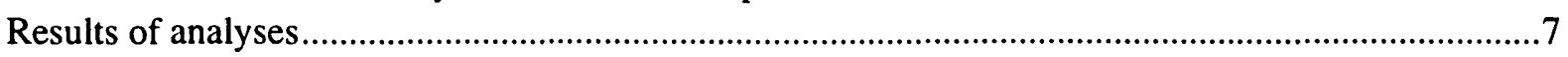

Cations, anions, and silica ……………………………………………………………..

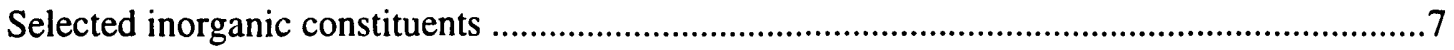

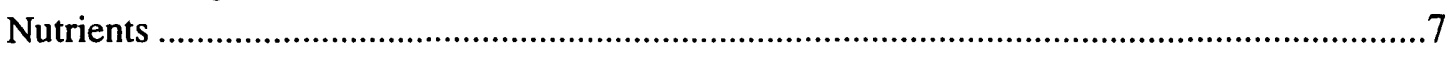

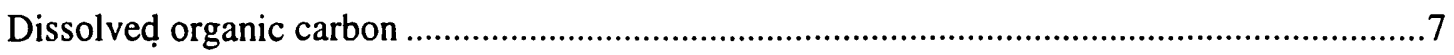

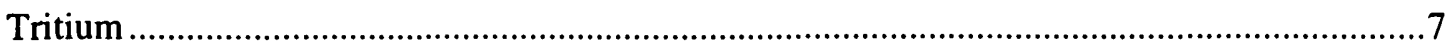

Gross alpha- and gross beta-particle radioactivity ...............................................................

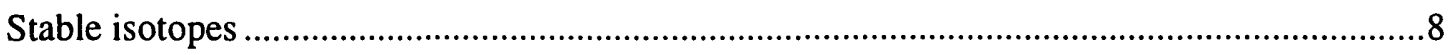

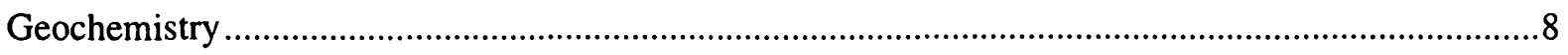

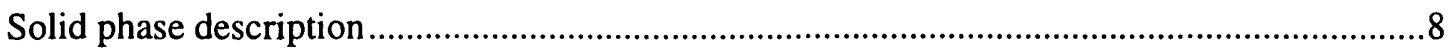

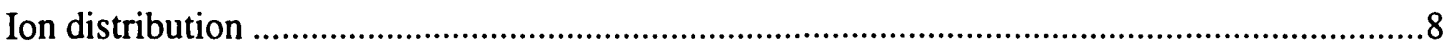

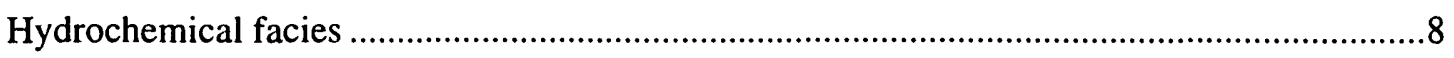

Thermodynamic considerations ..........................................................................................9

Plausible chemical reactions ..........................................................................................9

Dissolution or precipitation of calcite .....................................................................

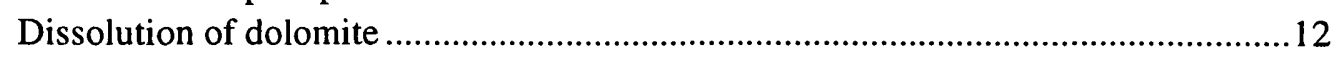

Geochemical modeling ...................................................................................................12

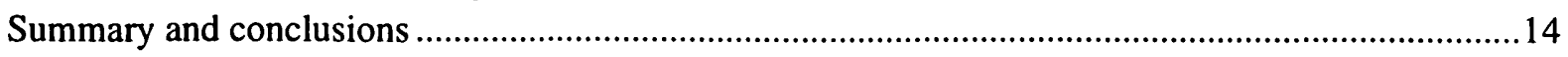

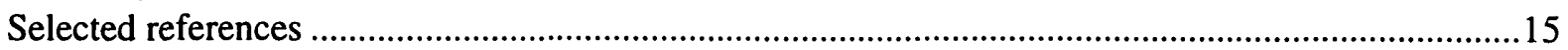

\section{FIGURES}

Figure 1. Map showing location of wells, Big Lost River drainage basin, Idaho ..................................

2. Graph showing concentrations of selected ions and silica in water from wells,

Big Lost River drainage basin

3. Trilinear diagram showing major-ion composition of water from wells, Big Lost

River drainage basin 


\section{TABLES}

Table 1. Containers and preservatives used for water samples, Big Lost River drainage basin

2. Well location, construction, and approximate depth to water, Big Lost River drainage basin

3. Results of field measurements for $\mathrm{pH}$, specific conductance, temperature of water, alkalinity, and dissolved oxygen, and laboratory calculations of total hardness and dissolved solids in water from selected wells, Big Lost River drainage basin

4. Standard deviation equations, concentration ranges, minimum reporting levels, and instrument detection limits for constituents analyzed by the National Water Quality Laboratory and Idaho State University

5. Concentrations of dissolved major cations and silica in water from selected wells, Big Lost River drainage basin .23

6. Concentrations of dissolved major anions in water from selected wells, Big Lost River drainage basin

7. Concentrations of dissolved trace elements in water from selected wells, Big Lost River drainage basin

8. Concentrations of dissolved nutrients and dissolved organic carbon in water from selected wells, Big Lost River drainage basin

9. Concentrations of tritium, gross alpha- and gross beta-particle radioactivity, and selected stable isotopes in water from selected wells, Big Lost River drainage basin

10. Mineral/water thermodynamic saturation indices for water from selected sites, Big Lost River drainage basin .27

11. Thermodynamically possible models obtained with NETPATH...

12. Models with thermodynamic impossibilities obtained with NETPATH 30

\section{CONVERSION FACTORS AND OTHER ABBREVIATED UNITS}

$\begin{array}{lc}\text { Multiply } & \underline{B y} \\ \text { inch (in.) } & 25.4 \\ \text { foot }(\mathrm{ft}) & .3048 \\ \text { square mile }\left(\mathrm{mi}^{2}\right) & 2.590 \\ \text { acre-foot }(\mathrm{acre}-\mathrm{ft}) & 1,233 \\ \text { cubic foot per second per mile }\left(\left(\mathrm{ft}^{3} / \mathrm{s}\right) / \mathrm{mi}\right) & .01760 \\ \text { picocurie per liter }(\mathrm{pCi} / \mathrm{L}) & .037\end{array}$

To obtain millimeter meter square kilometer cubic meter

For temperature, degrees Celsius $\left({ }^{\circ} \mathrm{C}\right)$ can be converted to degrees Fahrenheit $\left({ }^{\circ} \mathrm{F}\right)$ by using the formula ${ }^{\circ} \mathrm{F}=(1.8)\left({ }^{\circ} \mathrm{C}\right)+32$.

Sea Level: in this report, "sea level" refers to the National Geodetic Vertical Datum of 1929, a geodetic datum derived from a general adjustment of the first-order level nets of the United States and Canada, formerly called "Sea Level Datum of 1929."

Abbreviated units used in report: $\mu \mathrm{g} / \mathrm{L}$ (microgram per liter), $\mathrm{mg} / \mathrm{L}$ (milligram per liter), $\mathrm{mmol} / \mathrm{kg}$ (millimole per kilogram water), ppm (parts per million), ppb (parts per billion), $\mathrm{mL}$ (milliliter), $\mu \mathrm{S} / \mathrm{cm}$ (microsiemens per centimeter at $25^{\circ} \mathrm{C}$ ), and $\mathrm{mol} / \mathrm{L}$ (moles per liter). 


\section{GEOCHEMISTRY OF THE BIG LOST RIVER DRAINAGE SYSTEM, IDAHO}

by Colleen Carkeet and Jeffrey J. Rosentreter, Idaho State University, and

Roy C. Bartholomay and LeRoy L. Knobel, U.S. Geological Survey

\section{Abstract}

The U.S. Geological Survey and Idaho State University, in cooperation with the U.S. Department of Energy, are conducting studies to describe the chemical character of ground water that moves as underflow from drainage basins into the Snake River Plain aquifer (SRPA) system at and near the Idaho National Engineering and Environmental Laboratory (INEEL) and the effects of these recharge waters on the geochemistry of the SRPA system. Each of these recharge waters has a hydrochemical character related to geochemical processes, especially water-rock interactions that occur during migration to the SRPA. Results of these studies will benefit ongoing and planned geochemical modeling of the SRPA at the INEEL by providing model input on the hydrochemical character of water.from each drainage basin.

For this study, water samples were collected from 10 wells in the Big Lost River drainage basin during 1999 and analyzed for selected inorganic constituents, dissolved organic carbon, stable isotopes, tritium, and selected gross measurements of radioactivity. One additional sample was collected as a quality-assurance replicate. Results show that water from the Big Lost River drainage basin has a calcium-magnesium bicarbonate character. The computer code NETPATH was used to evaluate geochemical mass-balance reactions in the Big Lost River basin. Chemical reactions of water with calcite, dolomite, and carbon dioxide gas were considered the dominant reactions. The Arco City well is the farthest downgradient well sampled in the basin, and water from this well can be geochemically modeled from water in upgradient wells. However, the Arco City well is 250 feet deep, and water from it could represent only the deep underflow into the SRPA. Water from the Owen well (114 feet deep) could better represent the shallow underflow into the SRPA; therefore, a combination of water from these two wells could represent the total underflow from the Big Lost River drainage basin into the SRPA. If a 50-percent contribution of water from both wells is assumed, Big Lost River basin recharge to the SRPA would contain 61 milligrams per liter $(\mathrm{mg} / \mathrm{L})$ calcium, $14.5 \mathrm{mg} / \mathrm{L}$ magnesium, $6.6 \mathrm{mg} / \mathrm{L}$ sodium, $1.2 \mathrm{mg} / \mathrm{L}$ potassium, 15.5 $\mathrm{mg} / \mathrm{L}$ silica, $0.2 \mathrm{mg} / \mathrm{L}$ fluoride, $6.4 \mathrm{mg} / \mathrm{L}$ chloride, $232 \mathrm{mg} / \mathrm{L}$ bicarbonate, and $21.5 \mathrm{mg} / \mathrm{L}$ sulfate.

\section{INTRODUCTION}

The U.S. Geological Survey (USGS), in cooperation with the U.S. Department of Energy, has developed an extensive borehole network for the collection of geohydrologic, hydraulic, geochemical, and radiochemical data to address concerns about contamination of the Snake River Plain aquifer (SRPA) at the Idaho National Engineering and Environmental Laboratory (INEEL). These data are used in interpretive studies to describe the temporal and spatial distribution of the radioactiveand chemical-waste solutes and to define and describe the processes that control their concentration and migration rates, including advection, dispersion, adsorption, dilution, radioactive decay, and chemical reactions.

\section{Chemical and radiochemical constituents in} ground water at the INEEL are derived from natural and anthropogenic processes involving reactions between the solid, liquid, and gaseous phases. These reactions are an important control on the fate and mobility of waste solutes in and through the unsaturated zone and the aquifer. Laboratory and field investigations are being conducted to facilitate inclusion of these geochemical and physical processes in a solute-transport model. Studies to describe the geochemistry and to quantify model input include calculations of the thermodynamic state of the water-rock system and reaction-path modeling of processes in the subsurface. Part of the USGS investigations at the INEEL include a study with Idaho State University (ISU) to evaluate the 
geochemical characteristics of water from drainage basins that recharge the SRPA at and near the INEEL.

The Big Lost River drainage basin contributes recharge to the SRPA system from surface flow onto the plain and as underflow from the Big Lost River valley. The geochemical character of ground water in the Big Lost River drainage basin is related to the water-rock interactions that occur during migration of the ground water to the SRPA. Ground water from this basin mixes with and changes the chemical character of the SRPA water. This study provides geochemical information on the Big Lost River drainage basin. Results from this study and from geochemical studies of other SRPA drainage basins will directly benefit ongoing and planned geochemical modeling of the SRPA system. In addition, this study provides significant information for use in numerical simulations of ground-water flow, solute transport, and heat-flow transport.

\section{Purpose and Scope}

The purpose of this study is to better define the geochemical character of water in the Big Lost River drainage basin and its effect on the geochemistry of the SRPA at and near the INEEL. During 1999 , water samples were collected from 10 wells for analysis of selected inorganic constituents, dissolved organic carbon (DOC), stable isotopes, tritium, and selected gross measurements of radioactivity. One quality-assurance replicate was also collected. Water samples were analyzed for selected ions and trace elements at the ISU Department of Chemistry under the direction of Dr. Jeffrey J. Rosentreter. Five quality-assurance duplicates were sent to the National Water Quality Laboratory (NWQL) for analyses. Selected isotope samples also were sent to the NWQL for analysis.

The ground-water-chemistry data were used to describe the ion distribution and the hydrochemical facies of the Big Lost River drainage basin. The thermodynamic condition of the ground water was determined by using the computer code NETPATH (Plummer and others, 1994). Solid-phase mineralogy data were compiled to facilitate formulation of plausible chemical reactions for hypothesis testing.
The set of plausible chemical reactions constitute a geochemical model that was tested using the massbalance approach contained in NETPATH. The techniques of geochemical analysis and modeling used in this study are similar to those used by Knobel and others (1997).

\section{Geohydrologic Conditions}

Geologic factors affect the amount and chemical content of water that flows over the surface, becomes soil moisture, or moves underground in the Big Lost River drainage basin. Alluvium and colluvium in the valley areas accept recharge and transmit large volumes of water. Also, much of the basin is underlain by limestone that transmits large quantities of water (Crosthwaite and others, 1970).

\section{Generalized geology}

A large variety of rock types make up the geologic framework of the Big Lost River drainage basin as described by Crosthwaite and others (1970). Consolidated sedimentary strata consisting mostly of limestone, dolomite, quartzite, sandstone, shale, and argillite occupy the mountainous areas. The strata have been folded and faulted, and are highly jointed. At some places, these rocks have been intruded by granitic rocks. The Challis Volcanics, consisting principally of latite-andesite flows, breccia, tuffs, and some conglomerate at the base of the formation, blanket a large part of the older consolidated sedimentary strata at altitudes ranging from 5,500 to $9,500 \mathrm{ft}$ above sea level. Glacial and stream deposits occupy the mountain valleys. Cemented older alluvium, alluvial fans, and river alluvium compose the fill material in the main valley, and much of the valley floor is covered with loam and gravelly loam soils. Basalt of the Snake River Group is present at the mouth of the basin.

\section{Surface water}

The Big Lost River drains more than $1,400 \mathrm{mi}^{2}$ of mountainous area that includes parts of the Lost River Range and Pioneer Range west of the INEEL (fig. 1). Downstream from Arco, flow in the Big Lost River infiltrates to the SRPA along its channel and at sinks and playas at the river's terminus. 
Since 1965, excess runoff has been diverted to spreading areas in the southwestern part of the INEEL where much of the water rapidly infiltrates to the aquifer (Bennett, 1990).

The average streamflow in the Big Lost River below Mackay Reservoir for the 83-year period of record (water years 1905, 1913-14, and 1920-99) was 225,500 acre-ft/year (Brennan and others, 2000). Streamflow in the Big Lost River below Mackay Reservoir was 274,900 acre-ft during the 1999 water year (Brennan and others, 2000). Recharge to the SRPA can be substantial downstream from Arco; measured infiltration losses at various discharges ranged from 1 to $28\left(\mathrm{ft}^{3} / \mathrm{s}\right) / \mathrm{mi}$ (Bennett, 1990, p. 1).

\section{Ground water}

Aquifers in the Big Lost River drainage basin are recharged primarily by infiltration of precipitation on surrounding mountains and foothills adjacent to valley lowlands. Additional recharge occurs as (1) seepage losses from streams, irrigation canals, drainage ditches, reservoirs, and lakes; (2) infiltration of irrigation water; (3) interaquifer flow; and (4) discharge from septic systems and drain wells.

Ground water/surface water relations in the valley lowlands are complex. Ground water can be recharged from streams where water-table altitudes are lower than stream-channel altitudes. Ground water can be discharged to streams where watertable altitudes are at or above stream-channel altitudes. In this study area, ground-water recharge or discharge occurs intermittently along the river. A distinctive feature of the Big Lost River drainage basin is that both upper reaches and lower reaches of this river are areas of ground-water recharge. Surface-water flows are large at several places in the basin, but much of the water supply is unused and leaves the basin as ground-water underflow (Crosthwaite and others, 1970).

\section{Acknowledgments}

The authors gratefully acknowledge the assistance and cooperation provided by Idaho State University. Special thanks go to Dr. Dennis P. Strommen of the Department of Chemistry for pro- viding laboratory space. The authors are grateful to Gordon Rattray, USGS hydrologist, Idaho Falls, Idaho, and Mark Hardy, USGS Water-Quality Specialist, Boise, Idaho, for technical review of this paper.

\section{GUIDELINES, METHODS, AND QUALITY ASSURANCE}

The methods used for collecting water samples and conducting analyses for selected chemicals generally followed the guidelines established by the USGS (Goerlitz and Brown, 1972; Stevens and others, 1975; Wood, 1981; Claassen, 1982; W.L. Bradford, USGS, written commun., 1985; Wershaw and others, 1987; Fishman and Friedman, 1989; Hardy and others, 1989; Faires, 1992; Fishman, 1993; and Wilde and others, 1998). The laboratory methods used at the ISU laboratory generally followed the procedures described in Fishman and Friedman (1989). The cations and trace elements were determined by using inductively coupled plasma spectrometry. The methods used in the field and quality-assurance practices are described in the following sections.

\section{Sample Containers and Preservatives}

Sample containers and preservatives differ depending on the constituents for which analyses are requested. Samples analyzed by the NWQL were placed in containers and preserved in accordance with laboratory requirements specified by Pritt and Jones (1989). Containers and preservatives were supplied by the NWQL and had undergone a rigorous quality control procedure (Pritt, 1989 , p. 75) to minimize potential for sample contamination. Samples analyzed by the ISU were placed in containers in accordance with laboratory requirements specified by the laboratory standard operating procedures. Table 1 lists the containers, preservatives, laboratories, and analyses performed.

\section{Sampling Locations and Sample Collection}

Water samples were collected from 10 wells (fig. 1 and table 2): 8 domestic wells (Wildhorse Guardstation, Fulton, Coates, Hill, Lambert, 


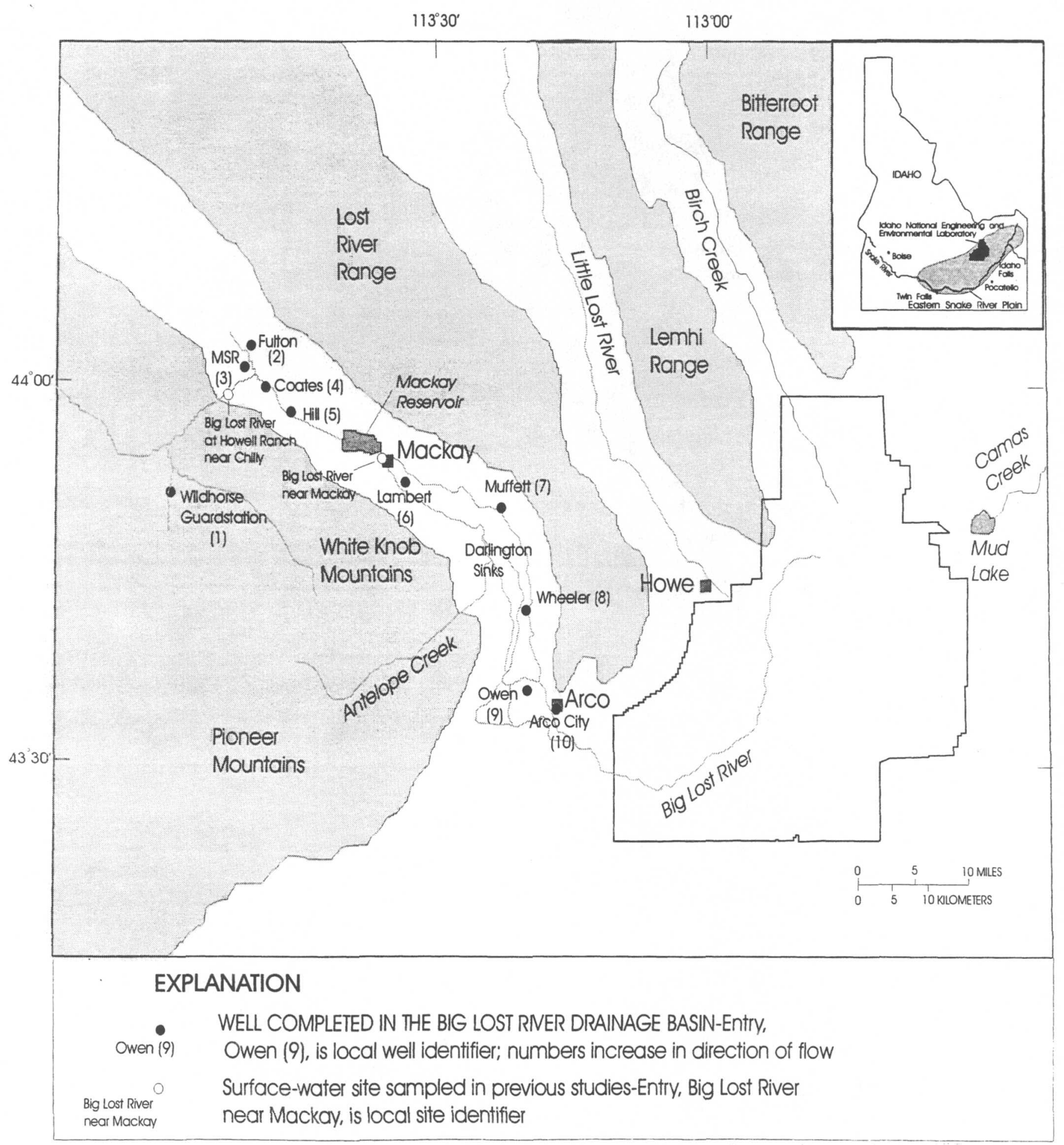

Figure 1. Location of wells, Big Lost River drainage basin, Idaho. 
Muffett, Wheeler, and Owen); 1 irrigation well (MSR); and 1 public supply well (Arco City). The domestic wells were equipped with dedicated submersible pumps. The irrigation and public supply wells were equipped with line-shaft turbine pumps.

Samples were collected from spigots as close to the pumps at the wells as possible to minimize contact with plumbing materials. Prior to sample collection, three field properties were monitored until stable readings, as defined by Mann (1996), were obtained: $\mathrm{pH}$, specific conductance, and water temperature. Between sample collection, all portable equipment was cleaned with deionized water. After collection, sample containers were sealed with laboratory film, labeled, and stored under secure conditions. Containers with water samples to be analyzed by the NWQL were placed in ice chests and the ice chests were sealed. The ice chests were shipped by overnight-delivery mail to the NWQL. Containers with water samples to be analyzed by ISU were hand-delivered to the laboratory.

Conditions at the sampling site during sample collection were recorded in a field logbook, and a chain-of-custody record was used to track samples from the time of collection until delivery to the analyzing laboratory. These records are available for inspection at the USGS INEEL Project Office. The results of field measurements for $\mathrm{pH}$, specific conductance, water temperature, alkalinity, and dissolved oxygen, and laboratory calculations of total hardness and dissolved solids are listed in table 3.

\section{Guidelines for Interpreting Results of Analyses}

Concentrations of inorganic and organic constituents are reported with reference to reporting limits. The laboratory reporting limit is the smallest measured concentration of a nonradioactive constituent that can be reliably reported using a given analytical method (Timme, 1995). Because of unpredictable matrix effects on detection limits, the laboratory reporting limits are set higher than the analytical method detection limits (Pritt and Jones, 1989).
Concentrations of radionuclides are reported with an estimated sample standard deviation, $\mathbf{s}$, that is obtained by propagating sources of analytical uncertainty in measurements. Guidelines for interpreting analytical results for radionuclides are based on an extension of a method by Currie (1984) and are presented by Knobel and others (1999).

As a matter of convention, concentrations of stable isotopes are reported as relative isotopic ratios (Toran, 1982). A more detailed description of stable isotope data is presented by Knobel and others (1999).

\section{Quality Assurance}

Detailed descriptions of internal quality control (QC) and the overall quality assurance (QA) practices used by the NWQL are provided in reports by Friedman and Erdmann (1982) and Jones (1987). The water samples were collected in accordance with a QA plan for quality-of-water activities conducted by personnel assigned to the INEEL Project Office; the plan was finalized in June 1989, updated in 1992 and in 1996 (Mann, 1996), and is available for inspection at the USGS INEEL Project Office. Comparative studies to determine agreement between analytical results for individual water-sample pairs by laboratories involved in the INEEL Project Office QA program were summarized by Wegner (1989) and Williams (1996, 1997). Additional QA for this sampling program included one full-suite replicate water sample collected from the Owen well. The routine and replicate samples were collected sequentially, marked with different identifiers, and sent to the laboratories. Analytical results from the QA replicate and similar data are discussed in subsequent sections of this report. Concentrations of the replicate were not included in the computation of descriptive statistical parameters. In addition to the QA replicate, five duplicate cation and trace element samples were collected and sent to the NWQL for analysis to assure the quality of the ISU laboratory data. The duplicate samples were collected from the Coates, Hill, Lambert, Wheeler, and Arco City wells. Also, the ISU laboratory participates in the USGS Branch of Technical Development and Quality System's standard reference water sample (SRWS) 
program. This program is an extensive interlaboratory comparison program in which approximately 150 laboratories are evaluated on the basis of results of their analyses of SRWS.

\section{EVALUATION OF QUALITY ASSUR- ANCE DATA}

Quality-assurance samples were compared by using Z-values as explained by Williams (1997). Test statistics were used to determine whether analytical results of pairs of samples were statistically equivalent. If the standard deviations are known, it is possible to determine, within a specified confidence level, whether the results of a replicate pair of samples are statistically equivalent. When the standard deviations are unknown, approximations of the standard deviations are used for the statistical comparison. The comparison can be made by using an adaptation of the equation to determine the standard deviate, $Z$, or the number of standard deviations the variable deviates from the mean (Volk, 1969, p. 55), where $\mathrm{Z}$ is the ratio of the absolute value of the difference between the two results and the square root of the sum of the squares of the standard deviations (the pooled standard deviation). In this way, two analytical results can be compared on the basis of the precision, or an approximation of the precision, associated with each of the results:

$$
Z=\frac{|x-y|}{\sqrt{\left(\left(s_{x}\right)^{2}+\left(s_{y}\right)^{2}\right)}},
$$

where

$x$ is the result of the routine water-quality sample, $y$ is the result of the QA replicate sample,

$\mathrm{s}_{x}$ is the standard deviation of $x$, and

$s_{y}$ is the standard deviation of $y$.

When the population is distributed normally and the standard deviation is known, the analytical results of replicate pairs can be considered statistically equivalent at the 95-percent confidence level if the Z-value is less than or equal to 1.96 . When the population is not distributed normally or an approximation of the standard deviation is used, a $\mathrm{Z}$-value less than or equal to 1.96 must be considered a guide when testing for equivalence. At the 95 -percent confidence level, the probability of error is 0.05 . In other words, when a Z-value is less than or equal to 1.96 , the results are within approximately two standard deviations of each other.

Equation 1 cannot be applied directly to results for which standard deviations are unknown. Because the laboratories did not report standard deviations for several constituents analyzed for this study, approximations of standard deviations, or most probable deviations for NWQL data and multi-laboratory standard deviations for ISU data (table 4), were used for these constituents.

\section{Inorganic Constituents}

Equation 1 was used to determine whether the analytical results for inorganic constituents in the replicate sample were statistically equivalent to those in the routine sample from the Owen well. Results for all 21 constituents (tables 5, 6, 7, and 8) were equivalent; Z-values for all pairs were 1.96 or less.

Duplicate cation and trace element samples also were analyzed by the NWQL for comparison with results determined by ISU. Not all results could be compared because of the number of trace element results reported as below detection limit by the NWQL. The Z-values for results available from both laboratories indicate that 31 of the 32 reported results were equivalent (tables 5 and 7); only magnesium concentrations in water from the Lambert well (reported values of 14 and $12 \mathrm{mg} / \mathrm{L}$, table 5) were not considered equivalent at the 95 -percent confidence level.

\section{Dissolved Organic Carbon}

Water samples were analyzed only by the NWQL for DOC; no duplicate samples were collected. Results for the routine and replicate samples from the Owen well were statistically equivalent; the $Z$-value was 0 (table 8 ).

\section{Radiochemical Analyses and Stable Isotopes}

Equation 1 was applied directly to determine whether the results for radiochemical analyses in the replicate samples were statistically equivalent 
to those in the routine samples from the Owen well. Because the NWQL reported radiochemical results at two standard deviations, it was necessary to divide the value by two to compute the one standard deviation required by equation 1 . Results for five of the six pairs of samples were equivalent. Tritium values were considered nonequivalent at the 95-percent confidence level because the Zvalue was 2.12 (table 9). Results for all three pairs of stable isotope data were equivalent.

\section{RESULTS OF ANALYSES}

\section{Cations, Anions, and Silica}

Water samples were analyzed for concentrations of dissolved cations (calcium, magnesium, sodium, and potassium) and dissolved silica by ISU (table 5) and anions (chloride, sulfate, and fluoride) by the NWQL (table 6). Field alkalinities expressed as concentrations of bicarbonate also are provided in table 6 . The ranges of concentrations, the median concentration, and the mean concentration for each constituent, excluding replicates follow: 25 to 74,55 , and $52 \mathrm{mg} / \mathrm{L}$ for calcium; 5.8 to $24,14.5$, and $14 \mathrm{mg} / \mathrm{L}$ for magnesium; 3.3 to 10 , 6.85 , and $6.7 \mathrm{mg} / \mathrm{L}$ for sodium; 0.68 to $1.4,1.2$, and $1.1 \mathrm{mg} / \mathrm{L}$ for potassium; 9.6 to $20,14.5$, and $14 \mathrm{mg} / \mathrm{L}$ for silica; 1.6 to $9.5,5.4$, and $5.2 \mathrm{mg} / \mathrm{L}$ for chloride; 12 to $26,19.5$, and $18 \mathrm{mg} / \mathrm{L}$ for sulfate; 89 to $296,217.5$, and $202 \mathrm{mg} / \mathrm{L}$ for bicarbonate; and 0.15 to $0.41,0.195$, and $0.22 \mathrm{mg} / \mathrm{L}$ for fluoride.

\section{Selected Inorganic Constituents}

Water samples were collected and analyzed for concentrations of dissolved aluminum, barium, bromide, chromium, iron, lead, manganese, strontium, and zinc (table 7).

Aluminum.-Concentrations in the 10 samples analyzed by ISU ranged from 2.8 to $9.4 \mu \mathrm{g} / \mathrm{L}$.

Barium.-Concentrations in the 10 samples analyzed by ISU ranged from 43 to $185 \mu \mathrm{g} / \mathrm{L}$.

Bromide.-Concentrations in the 10 samples analyzed by NWQL ranged from less than 10 to $50 \mu \mathrm{g} / \mathrm{L}$.
Chromium.-Concentrations in the 10 samples analyzed by ISU ranged from an estimated 2.1 to $22 \mu \mathrm{g} / \mathrm{L}$.

Iron.-Concentrations in the 10 samples analyzed by ISU ranged from an estimated 0 to $655 \mu \mathrm{g} / \mathrm{L}$.

Lead.-Concentrations in the 10 samples analyzed by ISU ranged from an estimated 0 to an estimated $8.4 \mu \mathrm{g} / \mathrm{L}$.

Manganese.-Concentrations in the 10 samples analyzed by ISU ranged from an estimated 0.14 to $18 \mu \mathrm{g} / \mathrm{L}$.

Strontium.-Concentrations in the 10 samples analyzed by ISU ranged from 161 to $686 \mu \mathrm{g} / \mathrm{L}$.

Zinc.-Concentrations in the 10 samples analyzed by ISU ranged from an estimated 7.2 to $56 \mu \mathrm{g} / \mathrm{L}$.

\section{Nutrients}

Concentrations of ammonia as nitrogen, nitrite as nitrogen, nitrite plus nitrate as nitrogen, and orthophosphate as phosphorous in the 10 water samples were determined by the NWQL (table 8). Concentrations of ammonia as nitrogen ranged from less than 0.02 to $0.03 \mathrm{mg} / \mathrm{L}$. Concentrations of nitrite as nitrogen were all less than $0.01 \mathrm{mg} / \mathrm{L}$. Concentrations of nitrite plus nitrate as nitrogen ranged from less than 0.05 to $2.1 \mathrm{mg} / \mathrm{L}$. Concentrations of orthophosphate as phosphorous ranged from 0.02 to $0.06 \mathrm{mg} / \mathrm{L}$.

\section{Dissolved Organic Carbon}

Concentrations of DOC in 10 samples were determined by the NWQL (table 8). Concentrations ranged from less than 0.1 to $0.9 \mathrm{mg} / \mathrm{L}$.

\section{Tritium}

Tritium, a radioactive isotope of hydrogen, is formed in nature by interactions of cosmic rays with gases in the upper atmosphere. Tritium also is produced in thermonuclear detonations and is a waste product of the nuclear-power industry. Ten 
water samples were collected and analyzed for tritium by the NWQL (table 9) and the concentrations ranged from $0.0 \pm 25.6$ to $83.2 \pm 25.6 \mathrm{pCi} / \mathrm{L}$.

\section{Gross Alpha- and Gross Beta-Particle Radioactivity}

Concentrations of gross alpha- and gross betaparticle radioactivity in 10 samples were determined by the NWQL (table 9).

Gross alpha-particle radioactivity.-Gross alpha-particle radioactivity is a measure of the total radioactivity given off as alpha particles during the radioactive decay process. For convenience, laboratories report the radioactivity as if it were all given off by one radionuclide. In this report, concentrations are reported as thorium-230 in picocuries per liter and ranged from $0.92 \pm 2.28$ to $4.96 \pm 3.28 \mathrm{pCi} / \mathrm{L}$.

Gross beta-particle radioactivity.-Gross betaparticle radioactivity is a measure of the total radioactivity given off as beta particles during the radioactive decay process. For convenience, laboratories report the radioactivity as if it were all given off by one radionuclide or a chemically similar pair of radionuclides in equilibrium. In this report, concentrations are reported as cesium-137 in picocuries per liter and ranged from $1.50 \pm 1.25$ to $5.23 \pm 1.18 \mathrm{pCi} / \mathrm{L}$.

\section{Stable Isotopes}

Water samples were analyzed for relative concentrations of stable isotopes of hydrogen $(\mathrm{H})$, oxygen ( $\mathrm{O}$ ), and carbon (C) by the NWQL (table 9). Relative isotopic ratios reported as $\delta^{2} \mathrm{H}$ in 10 samples ranged from -141.7 to -130.7 permil. Relative isotopic ratios reported as $\delta^{18} \mathrm{O}$ in 10 samples ranged from -18.37 to -17.19 permil. Relative isotopic ratios reported as $\delta^{13} \mathrm{C}$ in 10 samples ranged from -12 to -7.88 permil.

\section{GEOCHEMISTRY}

\section{Solid Phase Description}

A summary of bulk mineralogy for sediment from the Big Lost River was presented by Bartho- lomay and others (1989). Quartz was reported to be the most abundant mineral in the channel deposits. Plagioclase feldspar, potassium feldspar, calcite, pyroxene, dolomite, and clay minerals of illite, smectite, and kaolinite also were found in variable abundances in samples from the Big Lost River channel. Most of the calcite in the channel deposits had formed as precipitation material on other minerals. Although neither anhydrite nor its hydrated analog, gypsum, was found in the channel deposits, Wood and Low (1988, p. D10) noted that anhydrite is present in eolian dust throughout the Snake River Plain. Potential sources of anhydrite are the sedimentary rocks in the Big Lost River basin (Robertson and others, 1974, p. 50-51). Wood and Low (1988, p. D10) also noted that calcite is widely distributed in the surficial material.

\section{Ion Distribution}

The distribution of major ions in ground water is controlled partially by the solubilities of minerals in the aquifer and by the ground-water flow system. Concentrations of solutes in ground water generally increase in the direction of ground-water flow until equilibrium between the solid, liquid, and gaseous phases is established. Once equilibrium is established, concentrations remain relatively constant until the equilibrium of the system is disrupted by other factors such as microbial activity, industrial or agricultural waste disposal, a change in mineralogy, or mixing with water from another source. A plot of major ions in water from the Big Lost River drainage basin (fig. 2) indicates that concentrations both increase and decrease in the general direction of ground-water flow. These fluctuations indicate disruptions in the equilibrium of the system.

\section{Hydrochemical Facies}

Hydrochemical facies are useful tools for describing the chemical character of ground water. The format for the hydrochemical facies diagram used in this report (fig. 3) was developed by Piper (1944) and is similar to one designed by Hill (1940). This diagram allows the plotting of relative concentrations of major anions and cations and the chemical character of multiple water samples. Freeze and Cherry (1979, p. 249-250) and Hem 
(1985, p. 178-179) briefly described the diagram and its uses. Figure 3 indicates that water from wells in the Big Lost River drainage basin generally is calcium-magnesium-bicarbonate in character. This water character is consistent with Big Lost River drainage data presented by Parliman (1982).

\section{Thermodynamic Considerations}

Chemical equilibrium is attained when a chemical system, under constant pressure and temperature conditions, is at its smallest possible energy level. This occurs when the free energy of the system is zero. Chemical systems tend to give off energy by means of chemical reaction until equilibrium is achieved. The deviation of a system from equilibrium can be expressed by determining the saturation index (SI) of a water that has a given chemical composition with respect to a mineral. SI is defined as follows:

$$
\mathrm{SI}=\log \frac{\mathrm{IAP}}{\mathrm{K}}
$$

where,

IAP = ion activity product, and

$\mathrm{K}=$ the equilibrium constant for the reaction.

A SI of zero indicates that the water is in equilibrium with respect to a reaction. The range from -0.100 to 0.100 also can be considered at equilibrium (Langmuir, 1971). A more negative SI indicates that the water is undersaturated, and a more positive SI indicates that the water is supersaturated. SI's of the 10 water samples were determined by using the computer program WATEQF (Plummer and others, 1978). In addition, the SI's of three previously published Big Lost River surface-water samples (Crosthwaite and others, 1970; Bartholomay, 1990; and Busenberg and others, 2000) that were used for mixing in some models were determined. Table 10 gives the SI's of the samples with respect to selected minerals believed to be active in the system. With respect to calcite, water samples from wells MSR, Coates, Hill, and the Big Lost River at Howell Ranch near Chilly were slightly undersaturated; samples from wells Fulton, Lambert, Muffett, and the Big Lost River near Mackay (Busenberg and others, 2000), were at equilibrium, and samples from wells Wildhorse
Guardstation, Wheeler, Owen, and Arco City, and the Big Lost River near Mackay (Bartholomay, 1990) were supersaturated. With respect to dolomite, samples from all wells and surface-water sites were undersaturated, except the sample from Wildhorse Guardstation, which was at equilibrium, and that from Big Lost River near Mackay (Bartholomay, 1990), which was saturated. With respect to anhydrite, all samples were undersaturated.

\section{Plausible Chemical Reactions}

Plausible chemical reactions are defined in this report as those likely to take place naturally in the Big Lost River drainage basin because (1) the requisite source minerals, liquids, and gases are present in the system; (2) thermodynamic conditions allow the reaction to proceed; and (3) the dissolved-, gaseous-, or solid-product phases either are present or can be accounted for by processes that remove them from the system. Robertson and others $(1974$, p. 45-50) presented several plausible chemical reactions that could be taking place in the Big Lost River drainage system. The predominant chemical reactions probably are related to water interaction with calcite and dolomite. The areal predominance of carbonate rocks in the system and the calcium-magnesium bicarbonate character of the water supports this theory.

\section{Dissolution or precipitation of calcite}

Calcite is widely distributed in the Big Lost River drainage basin from carbonate rocks along the valley. The SI's (table 10) indicate that water samples were slightly undersaturated to supersaturated depending on location in the system. This indicates that precipitation and dissolution of calcite is occurring in the system. The chemical reaction model for calcite is

$$
\mathrm{CaCO}_{3}+\mathrm{CO}_{2}+\mathrm{H}_{2} \mathrm{O} \leftrightarrow \mathrm{Ca}^{2+}+2 \mathrm{HCO}_{3}^{-},
$$

where

$\mathrm{CaCO}_{3}=$ calcite,

$\mathrm{CO}_{2}=$ carbon dioxide,

$\mathrm{H}_{2} \mathrm{O}=$ water,

$\mathrm{Ca}^{2+}=$ dissolved calcium, and

$\mathrm{HCO}_{3}{ }^{-}=$dissolved bicarbonate. 


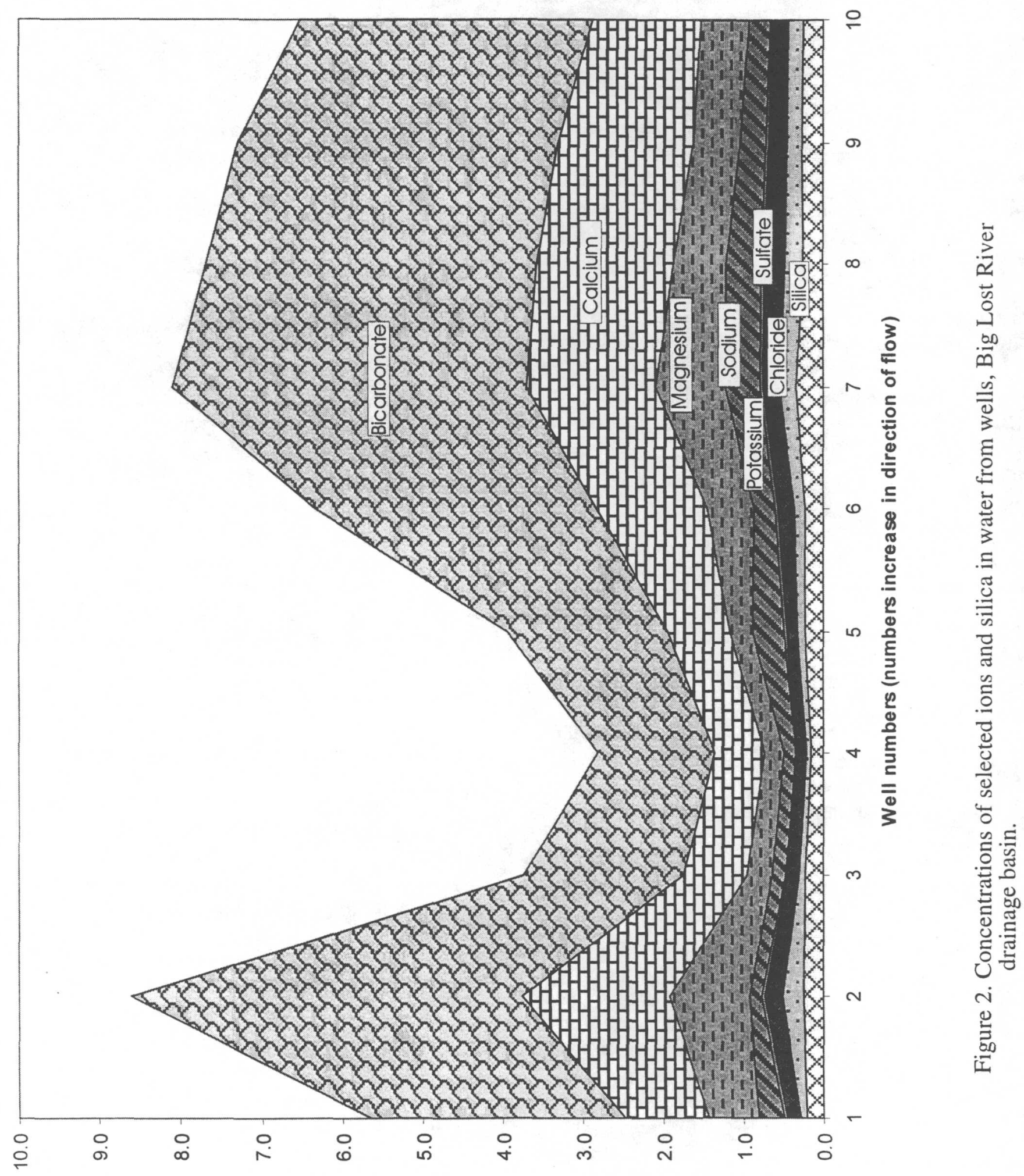

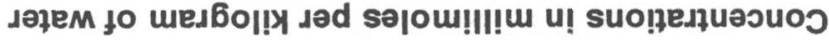




\section{EXPLANATION}

1 Wildhorse Guardstation 2 Fulton

3 MSR

4 Coates

5 Hill

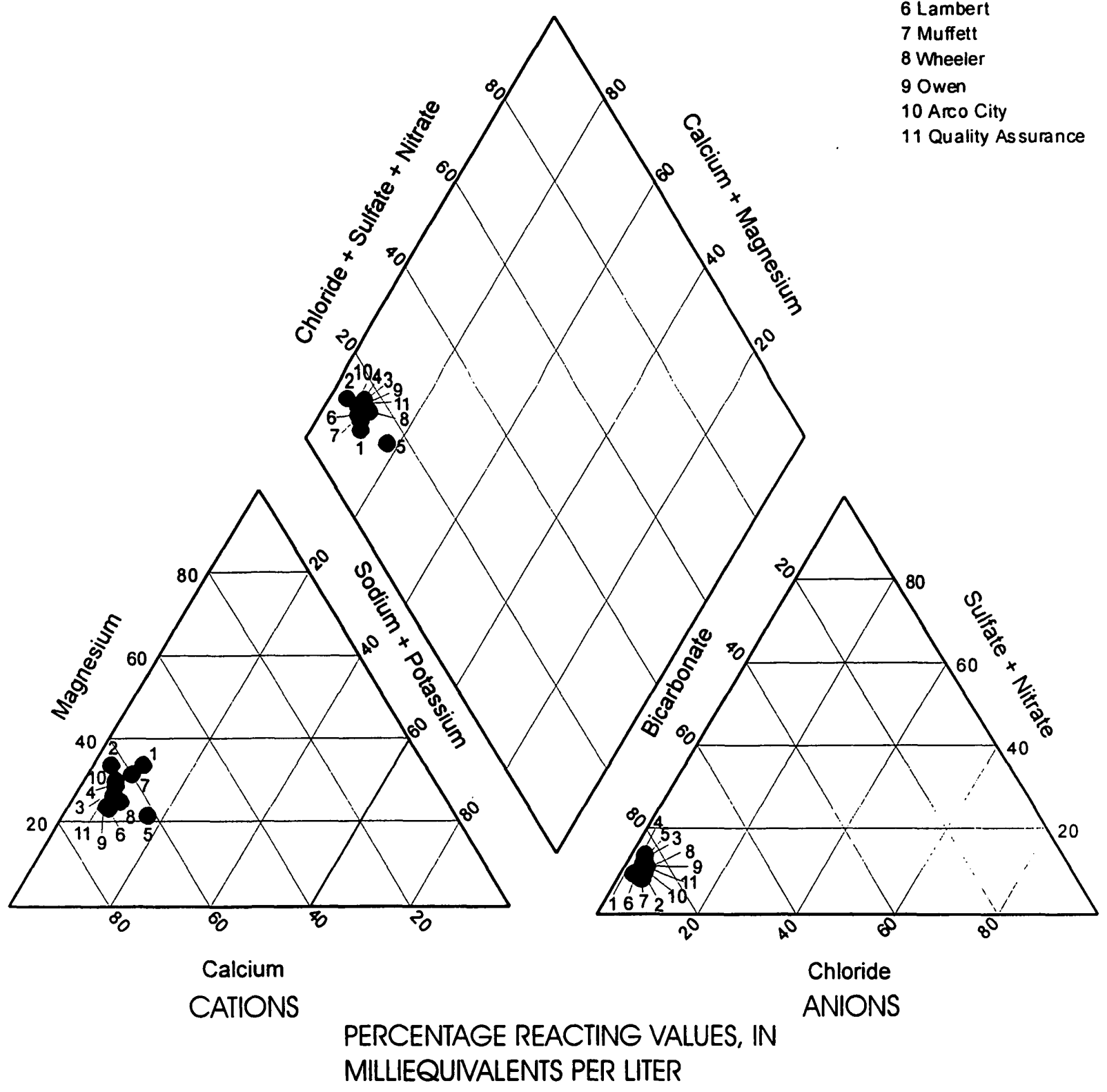

Figure 3. Major-ion composition of water from wells, Big Lost River drainage basin. 


\section{Dissolution of dolomite}

Dolomite also is widely distributed in the Big Lost River drainage basin from carbonate rocks along the valley. The SI's (table 10) indicate that water samples were slightly undersaturated in most of the system. This indicates that dissolution is the only thermodynamic possibility. The chemical reaction model for dolomite is

$$
\begin{aligned}
& \mathrm{CaMg}\left(\mathrm{CO}_{3}\right)_{2}+2 \mathrm{H}_{2} \mathrm{O}+2 \mathrm{CO}_{2} \rightarrow \mathrm{Ca}^{2+}+\mathrm{Mg}^{2+}+ \\
& 4 \mathrm{HCO}_{3}{ }^{-} \text {, }
\end{aligned}
$$

where

$\mathrm{CaMg}\left(\mathrm{CO}_{3}\right)_{2}=$ dolomite,

$\mathrm{H}_{2} \mathrm{O}=$ water,

$\mathrm{CO}_{2}=$ carbon dioxide,

$\mathrm{Ca}^{2+}=$ dissolved calcium,

$\mathrm{Mg}^{2+}=$ dissolved magnesium, and

$\mathrm{HCO}_{3}{ }^{-}=$dissolved bicarbonate.

\section{Geochemical Modeling}

The computer code NETPATH (Plummer and others, 1994) was used to model the net geochemical mass-balance reactions in the Big Lost River drainage. Selected model results are given in tables 11 and 12.

Initial attempts using all the major ions as constraints and representative minerals present in the system as phases resulted in no models. Further evaluation of the major ions in the system (fig. 2) indicated that silica, potassium, sodium, and chloride all were present in relatively small concentrations and uniformly distributed across the system; therefore, these ions were not used as constraints after the initial modeling. Sulfur also was present in small concentrations, but because of elevated concentrations in some wells, it was used as a constraint in some models. Because anhydrite is not considered as a phase in NETPATH, the hydrated analog (gypsum) was used as a surrogate phase for modeling purposes. Calcium, magnesium, and carbon were considered the major constraints, and calcite, dolomite, and carbon dioxide $\left(\mathrm{CO}_{2}\right)$ gas were considered the major phases because of their abundance in the system.
The upper part of the Big Lost River drainage basin (above Mackay Reservoir) is represented by a variety of water (fig. 2). Three wells, Wildhorse Guardstation (1), Fulton (2), and MSR (3) (fig. 1) represent ground water from three different drainage systems. Wildhorse Guardstation, a deep well with shallow water (table 2), represents a high altitude mountain drainage. Fulton, a well with shallow water (table 2), represents a drainage with a significant amount of spring discharge. MSR, an irrigation well with deep water (table 2) in the center of the basin represents a heavily irrigated drainage. The Coates (4) and Hill (5) wells both represent water near the center of the basin near the Big Lost River. An attempt to mix water from the first three wells to obtain water in the Coates well was unsuccessful (table 12), no models resulted. Results of several models that used water from the first three wells were thermodynamically possible, but most of these models were unreasonable because of phase/constraint relations. For example, mixing Wildhorse Guardstation and Fulton water to obtain MSR water resulted in a thermodynamically possible model that shows dolomite and $\mathrm{CO}_{2}$ gas precipitating (table 11). This model is unreasonable, though, because there is not much evidence in the geologic record that dolomite forms as a primary precipitate (Krauskopf, 1979, p. 72). Because mixing waters from the upper drainages (wells 1-3, fig. 1) did not result in reasonable models of water from downgradient wells (4 and 5), it is assumed that the chemistry of the water in downgradient wells is not directly affected by that of water in the three upgradient wells; therefore, the upgradient wells are not discussed further.

The changes in ground-water chemistry in the Big Lost River drainage basin between the Coates well (4) and the Arco City well (10) (fig. 2) can be explained by a series of chemical models. In some cases, more than one model can be used to explain the changes in observed water chemistry. Each chemical model covers a discrete segment of distance in the general direction of ground-water flow. The concentrations of calcium, magnesium, and bicarbonate in water from the Coates well were small relative to those in water from downgradient wells; concentrations increased between the Coates well (4) and the Muffett well (7). From the Muffett well to the Arco City well, the concentrations 
decreased slightly. These increases and decreases are related partly to water-rock reactions and the complex interactions between surface water and ground water in this system. The Big Lost River disappears and reappears several times during its descent to the Snake River Plain (Crosthwaite and others, 1970).

Coates-Hill.-Between the Coates and Hill wells, the concentrations of calcium, magnesium, and bicarbonate increased from 25 to $31,5.8$ to 6.7 and 89 to $123 \mathrm{mg} / \mathrm{L}$, respectively (tables 5,6 ). Water samples from both wells were thermodynamically undersaturated with respect to calcite, dolomite, and anhydrite (table 10). This implies that dissolution of these minerals is consistent with the observed conditions for these sites. Two chemical models meeting these conditions were found (table 11): (1) dissolving 0.122 millimoles per kilogram $(\mathrm{mmol} / \mathrm{kg}$ ) calcite and $0.037 \mathrm{mmol} / \mathrm{kg}$ dolomite, and (2) dissolving $0.096 \mathrm{mmol} / \mathrm{kg}$ calcite, $0.037 \mathrm{mmol} / \mathrm{kg}$ dolomite, and $0.026 \mathrm{mmol} / \mathrm{kg}$ gypsum (table 11). Although the second model can account for the chemistry changes, the simpler calcite-dolomite model is more reasonable because of the abundance of calcite in the system.

Hill-Lambert.-Between the Hill and Lambert wells, the concentrations of calcium, magnesium, and bicarbonate increased from 31 to $56,6.7$ to 14 , and 123 to $213 \mathrm{mg} / \mathrm{L}$, respectively (tables 5,6 ). Water in both wells was undersaturated with respect to dolomite and anhydrite, and the Hill well was undersaturated with respect to calcite. This implies that dissolution of these minerals is consistent with the observed conditions for these sites. Two chemical models meeting these conditions were found (table 11): (1) dissolving $0.324 \mathrm{mmol} /$ $\mathrm{kg}$ calcite and $0.297 \mathrm{mmol} / \mathrm{kg}$ dolomite, and (2) dissolving $0.275 \mathrm{mmol} / \mathrm{kg}$ calcite, $0.297 \mathrm{mmol} / \mathrm{kg}$ dolomite, and $0.490 \mathrm{mmol} / \mathrm{kg}$ gypsum. The first model is the more reasonable of these two models because of the abundance of calcite in the system. It is probable that similar models could be constructed to account for chemistry changes between the Coates and Lambert wells.

Lambert-Muffett.-Between the Lambert and Muffett wells, the concentrations of calcium, magnesium, and bicarbonate increased from 56 to 65 , 14 to 21 , and 213 to $269 \mathrm{mg} / \mathrm{L}$, respectively (tables
$5,6)$. Water from both wells was undersaturated with respect to dolomite and anhydrite, and near saturation with respect to calcite. This implies that dissolution of dolomite and gypsum and dissolution or precipitation of calcite are the thermodynamic possibilities between these two wells. Two chemical models were found that meet these conditions (table 11): (1) precipitating $0.064 \mathrm{mmol} / \mathrm{kg}$ calcite and dissolving $0.280 \mathrm{mmol} / \mathrm{kg}$ dolomite, and (2) precipitating $0.073 \mathrm{mmol} / \mathrm{kg}$ calcite and dissolving $0.280 \mathrm{mmol} / \mathrm{kg}$ of dolomite and 0.009 $\mathrm{mmol} / \mathrm{kg}$ of gypsum. It is also possible from a mass-balance and thermodynamic perspective to mix water from the Hill well with water from the Lambert well and simultaneously dissolve dolomite with or without dissolving gypsum. However, it is unlikely that mixing of water from these two wells could occur without being affected by water from the Mackay Reservoir.

Muffett-Wheeler.-From the Muffett well to the Arco City well, concentrations of calcium, magnesium, and bicarbonate decreased from 65 to 54,21 to 15 , and 269 to $222 \mathrm{mg} / \mathrm{L}$, respectively (tables 5,6). These decreases indicate a shift in chemical processes in the system. Between the Muffett and Wheeler wells, there was a slight increase in calcium concentrations from 65 to $69 \mathrm{mg} / \mathrm{L}$ and a decrease in bicarbonate concentrations from 269 to $251 \mathrm{mg} / \mathrm{L}$. Only one of the models tested can account for these changes: dissolution of $0.098 \mathrm{mmol} / \mathrm{kg}$ calcite and precipitation of $0.632 \mathrm{mmol} / \mathrm{kg} \mathrm{CO}_{2}$ gas (table 11). For this to happen, supersaturation of calcite would have to be achieved with subsequent precipitation of calcite and removal of $\mathrm{CO}_{2}$ gas from the system. This situation has been observed at springs where pressure and temperature changes of the water take place (Mason and Berry, 1968, p. 150; Hanor, 1978). The Big Lost River changes from a gaining stream to a losing stream at Darlington Sinks (Crosthwaite and others, 1970), downstream from the Muffett well, and then changes back to a gaining stream before it reaches the Wheeler well. This change in surfaceand ground-water relations is the probable cause of the change in water chemistry from increasing to decreasing major ion composition.

Wheeler-Owen.-Between the Wheeler and Owen wells, concentrations of calcium and bicar- 
bonate decreased from 69 to 68 and 251 to $243 \mathrm{mg} / \mathrm{L}$, respectively (table 5, 6). Water from both wells was supersaturated with respect to calcite (table 10) and precipitation of $0.025 \mathrm{mmol} / \mathrm{kg}$ calcite (table 11) is consistent with the observed water-chemistry change between these two wells.

Owen-Arco City.-Between the Owen and Arco City wells, concentrations of calcium and bicarbonate decreased from 68 to 54 and 243 to $222 \mathrm{mg} / \mathrm{L}$, respectively (tables 5, 6). Magnesium concentrations increased from 14 to $15 \mathrm{mg} / \mathrm{L}$. Water from both wells was supersaturated with respect to calcite and undersaturated with respect to dolomite and anhydrite (table 10). Precipitation of $0.358 \mathrm{mmol} / \mathrm{kg}$ calcite and dissolution of $0.028 \mathrm{mmol} / \mathrm{kg}$ dolomite (table 11 ), is consistent with the observed changes in water chemistry between these two wells.

To describe the chemistry of water recharging the SRPA from the Big Lost River drainage basin, the Arco City well can be used because it is the furthest downgradient well sampled in the drainage basin and water from this well can be geochemically modeled from water in upgradient wells. However, the Arco City well is $250 \mathrm{ft}$ deep, and water from it may represent only the deeper underflow into the SRPA. Water from the Owen well (114 ft deep) could represent the shallow underflow into the SRPA. A combination of these two waters could represent the total underflow from the Big Lost River drainage basin into the SRPA. If a 50-percent contribution of water from both wells is assumed, Big Lost River basin recharge to the SRPA would contain $61 \mathrm{mg} / \mathrm{L}$ calcium, $14.5 \mathrm{mg} / \mathrm{L}$ magnesium, $6.6 \mathrm{mg} / \mathrm{L}$ sodium, $1.2 \mathrm{mg} / \mathrm{L}$ potassium, $15.5 \mathrm{mg} / \mathrm{L}$ silica, $0.2 \mathrm{mg} / \mathrm{L}$ fluoride, $6.4 \mathrm{mg} / \mathrm{L}$ chloride, $232 \mathrm{mg} / \mathrm{L}$ bicarbonate, and $21.5 \mathrm{mg} / \mathrm{L}$ sulfate.

\section{SUMMARY AND CONCLUSIONS}

Water samples collected during 1999 from 10 wells in the Big Lost River drainage basin were analyzed for selected inorganic constituents, dissolved organic carbon, stable isotopes, tritium, and selected gross measurements of radioactivity. One quality assurance replicate and five duplicates also were collected and analyzed. The ranges of concentrations for dissolved cations, anions, and silica follow: calcium, 25 to $74 \mathrm{mg} / \mathrm{L}$; magnesium, 5.8 to $24 \mathrm{mg} / \mathrm{L}$; sodium, 3.3 to $10 \mathrm{mg} / \mathrm{L}$; potassium, 0.68 to $1.4 \mathrm{mg} / \mathrm{L}$; silica, 9.6 to $20 \mathrm{mg} / \mathrm{L}$; chloride, 1.6 to $9.5 \mathrm{mg} / \mathrm{L}$; sulfate, 12 to $26 \mathrm{mg} / \mathrm{L}$; bicarbonate, 89 to $296 \mathrm{mg} / \mathrm{L}$; and fluoride, 0.15 to $0.41 \mathrm{mg} / \mathrm{L}$.

The ranges of concentrations for aluminum, barium, bromide, chromium, iron, lead, manganese, strontium, and zinc were 2.8 to $9.4 \mu \mathrm{g} / \mathrm{L}, 43$ to $185 \mu \mathrm{g} / \mathrm{L},<10$ to $50 \mu \mathrm{g} / \mathrm{L}$, an estimated 2.1 to $22 \mu \mathrm{g} / \mathrm{L}$, an estimated 0 to $655 \mu \mathrm{g} / \mathrm{L}$, an estimated 0 to an estimated $8.4 \mu \mathrm{g} / \mathrm{L}$, an estimated 0.14 to $18 \mu \mathrm{g} / \mathrm{L}, 161$ to $686 \mu \mathrm{g} / \mathrm{L}$, and an estimated 7.2 to $56 \mu \mathrm{g} / \mathrm{L}$, respectively. Concentrations of dissolved organic carbon ranged from less than 0.1 to $0.9 \mathrm{mg} / \mathrm{L}$.

Tritium concentrations in the 10 samples ranged from $0.0 \pm 25.6$ to $83.2 \pm 25.6 \mathrm{pCi} / \mathrm{L}$. Concentrations of dissolved gross alpha-particle radioactivity reported as thorium-230 ranged from $0.92 \pm 2.28$ to $4.96 \pm 3.28 \mathrm{pCi} / \mathrm{L}$. Concentrations of dissolved gross beta-particle radioactivity reported as cesium-137 ranged from $1.50 \pm 1.25$ to $5.23 \pm 1.18$ $\mathrm{pCi} / \mathrm{L}$. Relative isotopic ratios ranged from -141.7 to -130.7 permil for $\delta^{2} \mathrm{H},-18.37$ to -17.19 permil for $\delta^{18} \mathrm{O}$, and -12 to -7.88 permil for $\delta^{13} \mathrm{C}$.

A statistical evaluation of quality assurance data indicated that all but one pair of replicate results were equivalent and all but one pair of duplicate results were equivalent.

The computer code NETPATH was used to model the net geochemical mass-balance reactions in the Big Lost River drainage basin. Calcium, magnesium, and carbon were determined to be the major constraints and calcite, dolomite, and $\mathrm{CO}_{2}$ gas were the major phases.

The upper part of the Big Lost River drainage basin (above Mackay Reservoir) is represented by a variety of water characters. Water samples from wells Wildhorse Guardstation, Fulton, and MSR were determined to represent three different drainages. It also was determined that these waters do not geochemically affect the water below Mackay Reservoir; therefore, they were not used for modeling water from downgradient wells. 
A step-wise series of models were used to describe the chemical composition of water as it moves downgradient from the Coates well (4) to the Arco City well (10). To describe the chemistry of water recharging the SRPA from the Big Lost River drainage basin, the Arco City well can be used because it is the furthest downgradient well sampled in the drainage basin and water from this well can be geochemically modeled from water in upgradient wells. However, the Arco City well is $250 \mathrm{ft}$ deep, and could represent only the deeper underflow into the SRPA. Water from the Owen well (114 ft deep), could better represent the shallow underflow into the SRPA. A combination of these two waters could represent the total underflow from the Big Lost River drainage basin into the SRPA. If a 50-percent contribution of water from both wells is assumed, Big Lost River basin recharge to the SRPA would contain $61 \mathrm{mg} / \mathrm{L} \mathrm{cal-}$ cium, $14.5 \mathrm{mg} / \mathrm{L}$ magnesium, $6.6 \mathrm{mg} / \mathrm{L}$ sodium, 1.2 $\mathrm{mg} / \mathrm{L}$ potassium, $15.5 \mathrm{mg} / \mathrm{L}$ silica, $0.2 \mathrm{mg} / \mathrm{L}$ fluoride, $6.4 \mathrm{mg} / \mathrm{L}$ chloride, $232 \mathrm{mg} / \mathrm{L}$ bicarbonate, and $21.5 \mathrm{mg} / \mathrm{L}$ sulfate.

\section{SELECTED REFERENCES}

American Public Health Association, 1992, Standard methods for the examination of water and wastewater; Greenberg, A.E., Clesceri, L.S., and Eaton, A.D., ed., $18^{\text {th }}$ ed., Washington D.C., [variously paged].

Barnett, P.R., and Mallory, E.C., 1981, Determination of minor elements in water by emission spectroscopy: U.S. Geological Survey Techniques of Water-Resources Investigations, book 5, chap. A2, 31 p.

Bartholomay, R.C., 1990, Mineralogy, petrology, and grain size of surficial sediment from the Big Lost River, Little Lost River, and Birch Creek drainages: Pocatello, Idaho, Idaho State University, M.S. thesis, 118 p.

Bartholomay, R.C., Knobel, L.L., and Davis, L.C., 1989, Mineralogy and grain size of surficial sediment from the Big Lost River drainage and vicinity, with chemical and physical characteristics of geologic materials from selected sites at the Idaho National
Engineering Laboratory, Idaho: U.S.

Geological Survey Open-File Report 89-384 (DOE/ID-22081), 74 p.

Bartholomay, R.C., Tucker, B.J., Ackerman, D.J., and Liszewski, M.J., 1997, Hydrologic conditions and distribution of selected radiochemical and chemical constituents in water, Snake River Plain aquifer, Idaho National Engineering Laboratory, Idaho, 1992 through 1995: U.S. Geological Survey Water-Resources Investigations Report 97-4086 (DOE/ID22137), $57 \mathrm{p}$.

Bennett, C.M., 1990, Streamflow losses and ground-water level changes along the Big Lost River at the Idaho National Engineering Laboratory, Idaho: U.S. Geological Survey Water-Resources Investigations Report 904067 (DOE/ID-22091), 49 p.

Brennan, T.S., Campbell, A.M., Lehmann, A.K., and O'Dell, I., 2000, Water resources data, Idaho, water year 1999-volume 1. Great Basin and Snake River Basin above King Hill: U.S. Geological Survey Water-Data Report ID-99-1, $392 \mathrm{p}$.

Busenberg, E., Plummer, L.N., Doughten, M.W., Widman, P.K., and Bartholomay, R.C., 2000, Chemical and isotopic composition and gas concentrations of ground water and surface water from selected sites at and near the Idaho National Engineering and Environmental Laboratory, Idaho, 1994-97: U.S. Geological Survey Open-File Report 00-81 (DOE/ID22164), $55 \mathrm{p}$.

Claassen, H.C., 1982, Guidelines and techniques for obtaining water samples that accurately represent the water chemistry of an aquifer: U.S. Geological Survey Open-File Report 82$1024,49 \mathrm{p}$.

Crosthwaite, E.G., Thomas, C.A., and Dyer, K.L., 1970, Water resources in the Big Lost River Basin, south-central Idaho: U.S. Geological Survey Open-File Report 70-93, 109 p.

Currie, L.A., 1984, Lower limit of detectiondefinition and elaboration of a proposed position for radiological effluent and 
environmental measurements: U.S. Nuclear Regulatory Commission NUREG/CR-4007, $139 \mathrm{p}$.

Faires, L.M., 1992, Methods of analysis by the U.S. Geological Survey National Water Quality Laboratory-determinations of metals in water by inductively coupled plasmamass spectrometry: U.S. Geological Survey Open-File Report 92-634, 28 p.

Fishman, M.J., ed., 1993, Methods of analysis by the U.S. Geological Survey National Water Quality Laboratory-determination of inorganic and organic constituents in water and fluvial sediments: U.S. Geological Survey Open-File Report 93-125, 217 p.

Fishman, M.J. and Friedman, L.C., 1989, Methods for determination of inorganic substances in water and fluvial sediments: U.S. Geological Survey Techniques of Water-Resources Investigations, book 5, chap. A1, 545 p.

Freeze, R.A., and Cherry, J.A., 1979, Groundwater: Englewood Cliffs, N.J., Prentice-Hall, 604 p.

Friedman, L.C., and Erdmann, D.E., 1982, Quality assurance practices for the chemical and biological analyses of water and fluvial sediments: U.S. Geological Survey Techniques of Water-Resources Investigations, book 5, chap. A6, 181 p.

Goerlitz, D.F., and Brown, E., 1972, Methods for analysis of organic substances in water: U.S. Geological Survey Techniques of WaterResources Investigations, book 5, chap. A3, $40 \mathrm{p}$.

Hanor, J.S., 1978, Precipitation of beachrock cements: Mixing of marine and meteoric waters vs. $\mathrm{CO}_{2}$-degassing: Journal of Sedimentary Petrology, v. 48, p. 489-501.

Hardy, M.A., Leahy, P.P., and Alley, W.M., 1989, Well installation and documentation and groundwater sampling protocols for the pilot National Water-Quality Assessment Program: U.S. Geological Survey Open-File Report 89396, 36 p.
Hem, J.D., 1985, Study and interpretation of the chemical characteristics of natural water $(3 d$ ed.): U.S. Geological Survey Water-Supply Paper 2254, $263 \mathrm{p}$.

Hill, R.A., 1940, Geochemical patterns in Coachella Valley, California: American Geophysical Union Transactions, v. 21, p. 46-49.

Jones, B.E., 1987, Quality control manual of the U.S. Geological Survey's National Water Quality Laboratory: U.S. Geological Survey Open-File Report 87-457, 17 p.

Knobel, L.L., Bartholomay, R.C., and Orr, B.R., 1997, Preliminary delineation of natural geochemical reactions, Snake River Plain aquifer system, Idaho National Engineering Laboratory and vicinity, Idaho: U.S. Geological Survey Water-Resources Investigations Report 97-4093 (DOE/ID-22139), 52 p.

Knobel, L.L., Bartholomay, R.C., Tucker, B.J., Williams, L.M., and Cecil, L.D., 1999, Chemical constituents in ground water from 39 selected sites with an evaluation of associated quality assurance data, Idaho National Engineering Laboratory and vicinity, Idaho: U.S. Geological Survey WaterResources Investigations Report 99-246 (DOE/ID-22159), $58 \mathrm{p}$.

Krauskopf, K.B., 1979, Introduction to geochemistry (2d ed.): New York, McGraw-Hill Book Company, $617 \mathrm{p}$.

Langmuir, Donald, 1971, The geochemistry of some carbonate groundwaters in central Pennsylvania: Geochimica et Cosmochimica Acta, v. 35, p. 1028-1045.

Maloney, T.J., Ludtke, A.S., and Krizman, T.L., 1993, Quality assurance for routine water analysis in the laboratories of the U.S. Geological Survey for Water-Year 1990: U.S. Geological Survey Water-Resources Investigations Report 93-4082, 145 p.

Mann, L.J., 1996, Quality-assurance plan and field methods for quality-of-water activities: U.S. Geological Survey Open-File Report 96-615 (DOE/ID-22132), $37 \mathrm{p}$. 
Mason, Brian, and Berry, L.G., 1968, Elements of mineralogy: San Francisco, W.H. Freeman and Company, $550 \mathrm{p}$.

Nace, R.L., Deutsch, Morris, and Voegeli, P.T., 1956, Geography, geology, and water resources of the National Reactor Testing Station, Idaho, part 2, geography and geology: U.S. Atomic Energy Commission Publication IDO-22033, 225 p.

Olmstead, F.H., 1962, Chemical and physical character of ground water in the National Reactor Testing Station, Idaho: U.S. Atomic Energy Publication IDO-22043, 81 p.

Parliman, D.J., 1982, Ground-water quality in eastcentral Idaho valleys: U.S. Geological Survey Open-File Report 81-1011, 55 p.

Piper, A.M., 1944, A graphic procedure in the geochemical interpretation of water analyses: American Geophysical Union transactions, v. 25, p. 914-923.

Plummer, L.N., Jones, B.F., and Truesdell, A.H., 1978, WATEQF-A FORTRAN IV version of WATEQ, a computer program for calculating chemical equilibrium of natural waters (rev. ed.): U.S. Geological Survey Water-Resources Investigations Report 76$13,63 \mathrm{p}$.

Plummer, L.N., Prestemon, E.C., and Parkhurst, D.L., 1994, An interactive code (NETPATH) for modeling NET geochemical reactions along a flow PATH version 2.0: U.S. Geological Survey Water-Resources Investigations Report 94-4169, 130 p.

Pritt, J.W., 1989, Quality assurance of sample containers and preservatives at the U.S. Geological Survey National Water Quality Laboratory, in Pederson, G.L., and Smith, M.M., compilers, U.S. Geological Survey Second National Symposium on Water Quality-Abstracts of the technical sessions, Orlando, Fla., November 12-17, 1989: U.S. Geological Survey Open-File Report 89-409, $111 \mathrm{p}$.
Pritt, J.W., and Jones, B.E., eds., 1989, 1990 National Water Quality Laboratory services catalog: U.S. Geological Survey Open-File Report 89-386 [variously paged].

Pritt, J.W., and Raese, J.W., eds., 1992, Quality assurance/quality control manual, National Water Quality Laboratory: U.S. Geological Survey Open-File Report 92-495, 33 p.

Robertson, J.B., Schoen, Robert, and Barraclough, J.T., 1974, The influence of liquid waste disposal on the geochemistry of water at the National Reactor Testing Station, Idaho: U.S. Geological Survey Open-File Report, IDO22053, 231 p.

Rose, D.L., and Schroeder, M.P., 1995, Methods of analysis by the U.S. Geological Survey National Water Quality Laboratorydetermination of volatile organic compounds in water by purge and trap capillary gas chromatograph/mass spectrometry: U.S. Geological Survey Open-File Report 94-708, $26 \mathrm{p}$.

Skougstad, M.W., Fishman, M.J., Friedman, L.C., Erdmann, D.E., and Duncan, S.S., eds., 1979, Methods for determination of inorganic substances in water and fluvial sediments: U.S. Geological Survey Techniques of WaterResources Investigations, book 5, chap. A1, $626 \mathrm{p}$.

Stevens, H.H., Jr., Ficke, J.F., and Smoot, G.F., 1975, Water temperature-influential factors, field measurement, and data presentation: U.S. Geological Survey Techniques of WaterResources Investigations, book 5, chap. D1, $65 \mathrm{p}$.

Thatcher, L.L., Janzer, V.J., and Edwards, K.W., 1977 , Methods for determination of radioactive substances in water and fluvial sediments: U.S. Geological Survey Techniques of WaterResources Investigations, book 5, chap. A5, $95 \mathrm{p}$.

Timme, P.J., 1995, National Water Quality Laboratory, 1995 services catalog: U.S. Geological Survey Open-File Report 95-352, $120 \mathrm{p}$. 
Toran, Laura, 1982, Isotopes in ground-water investigations: Groundwater, v. 20, no. 6, p. 740-745.

Volk, William, 1969, Applied statistics for engineers ( $2 \mathrm{~d}$ ed.): New York, McGraw-Hill Book Company, 415 p.

Wegner, S.J., 1989, Selected quality assurance data for water samples collected by the U.S. Geological Survey, Idaho National Engineering Laboratory, 1980 to 1988: U.S. Geological Survey Water-Resources Investigations Report 89-4168 (DOE/ID-22085), 91 p.

Wershaw, R.L., Fishman, M.J., Grabbe, R.R., and Lowe, L.E., 1987, Methods for the determination of organic substances in water and fluvial sediments: U.S. Geological Survey Techniques of Water-Resources Investigations, book 5, chap. A3, 80 p.

Wilde, F.D., Radtke, D.B., Gibs, Jacob, and Iwatsubo, R.T., 1998, National field manual for the collection of water-quality data: U.S. Geological Survey Techniques of WaterResources Investigations, book 9 [variously paged].
Williams, L.M., 1996, Evaluation of quality assurance/quality control data collected by the U.S. Geological Survey for water-quality activities at the Idaho National Engineering Laboratory, Idaho, 1989 through 1993: U.S. Geological Survey Water-Resources Investigations Report 96-4148 (DOE/ID-22129), 115 p.

-1997, Evaluation of quality assurance/quality control data collected by the U.S. Geological Survey for water-quality activities at the Idaho National Engineering Laboratory, Idaho, 1994 through 1995: U.S. Geological Survey WaterResources Investigations Report 97-4058 (DOE/ID-22136), $87 \mathrm{p}$.

Wood, W.W., 1981, Guidelines for collection and field analysis of ground-water samples for selected unstable constituents: U.S. Geological Survey Techniques of WaterResources Investigations, book 1, chap. D2, $24 \mathrm{p}$.

Wood, W.W., and Low, W.H., 1988, Solute geochemistry of the Snake River Plain regional aquifer system, Idaho and eastern Oregon: U.S. Geological Survey Professional Paper 1408-D, $79 \mathrm{p}$. 


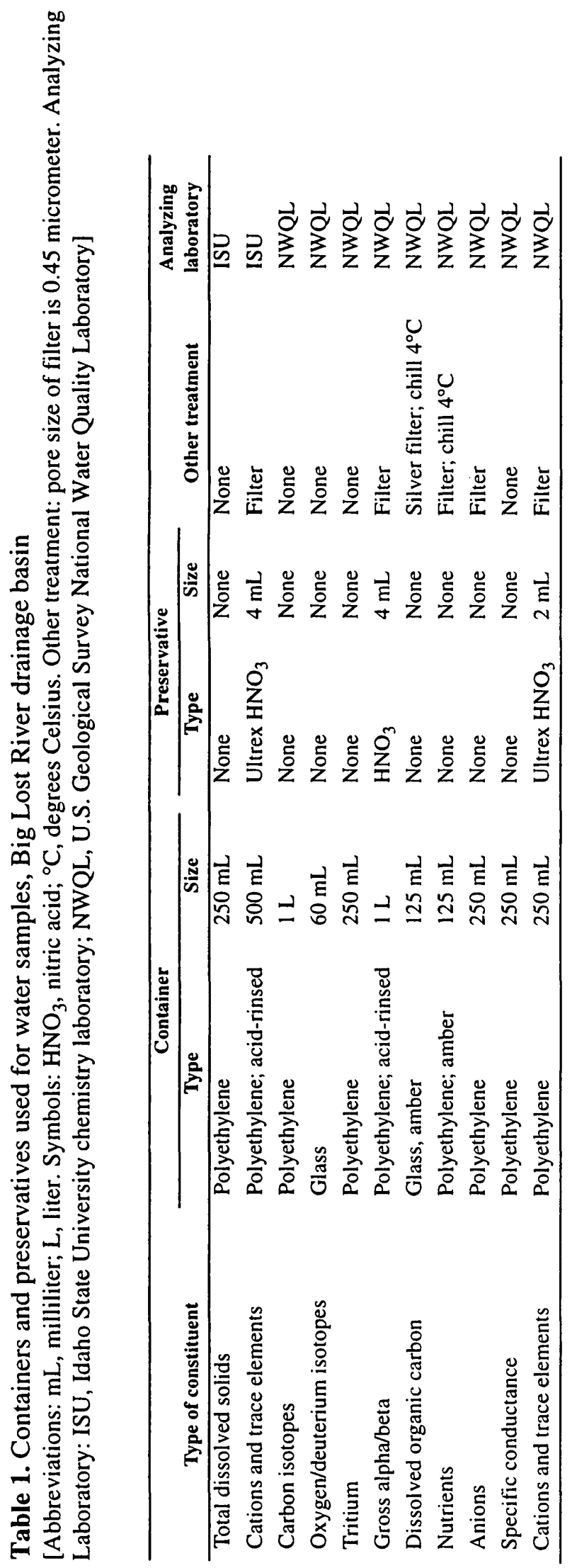


Table 2. Well location, construction, and approximate depth to water, Big Lost River drainage basin [See figure 1 for location of wells. Abbreviations: NA, data not available. Symbols: *, quality assurance replicate collected at well; $\sim$, approximate]

\begin{tabular}{llllrrr}
\hline \multicolumn{1}{c}{ Well } & Latitude & Longitude & Well type & $\begin{array}{r}\text { Well } \\
\text { depth } \\
\text { (feet) }\end{array}$ & $\begin{array}{r}\text { Depth to } \\
\text { water (feet) }\end{array}$ & $\begin{array}{c}\text { Diameter of } \\
\text { casing (inches) }\end{array}$ \\
\hline Wildhorse Guardstation & 435311 & 1140601 & Domestic & 264 & 13.87 & NA \\
Fulton & 440803 & 1135417 & Domestic & 30 & 8.23 & NA \\
MSR & 440454 & 1135544 & Irrigation & NA & 75.27 & 16 \\
Coates & 440323 & 1135334 & Domestic & 88 & 37.62 & 6 \\
Hill & 435956 & 1134925 & Domestic & 80 & NA & NA \\
Lambert & 435351 & 1133503 & Domestic & 50 & 5.02 & 6 \\
Muffett & 435011 & 1132232 & Domestic & 63 & 36.08 & 6 \\
Wheeler & 434345 & 1132034 & Domestic & 80 & 48.49 & 6 \\
Owen* & 433908 & 1132031 & Domestic & 114 & 41.87 & 6 \\
Arco City & 433758 & 1131801 & Public supply & 250 & -132 & 20 \\
\hline
\end{tabular}




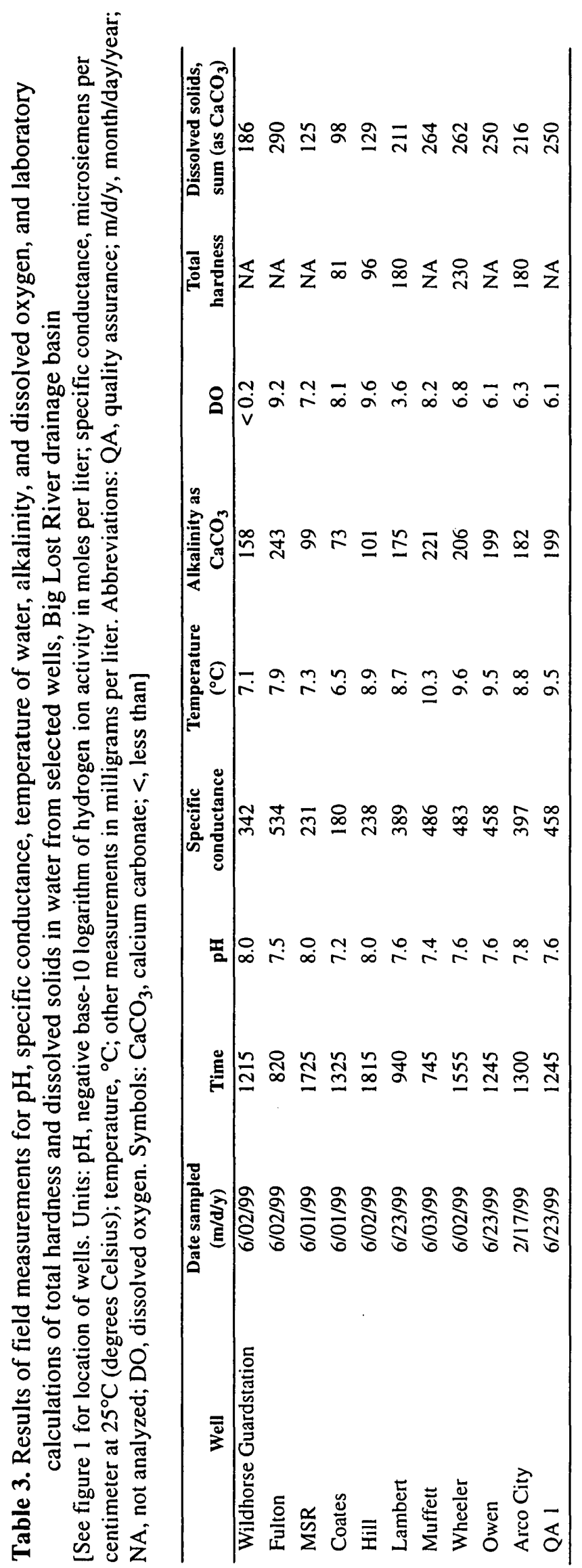


Table 4. Standard deviation equations, concentration ranges, minimum reporting levels, and instrument detection limits for constituents analyzed by the National Water Quality Laboratory and Idaho State University

[The range given for the National Water Quality Laboratory (NWQL) is in the units designated in the constituent column. In the MPD (most probable deviation) equations, ' $Y$ ' is the MPD and ' $x$ ' is the concentration value obtained from the analysis. For multi-laboratory standard deviation equations, ' $S$ ' is the standard deviation and ' $X$ ' is the concentration value obtained from the analysis. To use these equations, the concentration value for a particular sample is plugged in as ' $\mathrm{x}$ and $\mathrm{X}$ ' and the ' $\mathrm{Y}$ and $\mathrm{S}$ ' obtained is the $+/$ - error for the value. Abbreviations: MRL, minimum reporting level; IDL, instrument detection limit as determined at ISU; $\mu \mathrm{g} / \mathrm{L}$, microgram per liter; $\mathrm{ppm}$, parts per million; ppb, parts per billion; NA, not applicable. Symbol: *, indicates only data available is based on Electrothermal Absorption Spectrometric methods. Multi-laboratory standard deviation and range obtained from APHA, 1992, p. 3-38]

\begin{tabular}{|c|c|c|c|c|c|c|}
\hline \multirow[b]{2}{*}{ Constituent } & \multicolumn{3}{|c|}{ NWQL } & \multicolumn{3}{|c|}{ ISU } \\
\hline & MPD equation & Range & MRL & $\begin{array}{c}\text { Multi-laboratory } \\
\text { standard deviation }\end{array}$ & $\begin{array}{l}\text { Range } \\
(\mu g / \mathrm{L})\end{array}$ & IDL \\
\hline $\mathrm{K}(\mathrm{ppm})$ & $Y=0.069 x+0.016$ & $0.45-13.1$ & .1 & $S=0.0934 X+77.8$ & $347-14,151$ & .10 \\
\hline $\mathrm{Ca}(\mathrm{ppm})$ & $Y=0.046 x+0.026$ & $5.13-78.9$ & .1 & $S=0.1228 X+10.1$ & $17-47,170$ & 3 \\
\hline $\mathrm{Na}(\mathrm{ppm})$ & $Y=0.038 x+0.202$ & $7.19-166$ & .06 & $S=0.2097 X+33.0$ & $35-47,140$ & 2 \\
\hline $\mathrm{Mg}(\mathrm{ppm})$ & $Y=0.039 x+0.026$ & $1.24-25.4$ & .004 & $S=0.0607 X+11.6$ & $34-13,868$ & .05 \\
\hline $\mathrm{Al}(\mathrm{ppb})$ & $Y=0.131 x+4.054$ & $6.66-171$ & 10 & $S=0.0559 X+18.6$ & $69-4,792$ & 1 \\
\hline $\mathrm{Fe}(\mathrm{ppb})$ & $Y=0.027 x+6.189$ & $4.30-474$ & 10 & $S=0.0683 X+11.5$ & $13-9,359$ & 11 \\
\hline $\mathrm{Mn}(\mathrm{ppb})$ & $Y=0.049 x+0.754$ & $2.40-424$ & 3 & $S=0.0324 X+0.88$ & $4-1,887$ & 4 \\
\hline $\mathrm{Cr}(\mathrm{ppb})$ & $Y=0.057 x+0.695$ & $0.68-79.0$ & 1 & $S=0.0499 X+4.4$ & $13-1,406$ & 17 \\
\hline $\mathrm{Zn}(\mathrm{ppb})$ & $Y=0.042 x+2.275$ & $5.80-218$ & 20 & $S=0.0914 X+3.75$ & $7-7,076$ & 25 \\
\hline $\mathrm{Pb}(\mathrm{ppb})$ & $Y=0.066 x+0.707$ & $1.00-103$ & 1 & $S=0.0558 X+7.0$ & $42-4,717$ & 16 \\
\hline $\mathrm{SiO}_{2}(\mathrm{ppm})$ & $Y=0.061 x+0.003$ & $1.43-24.0$ & .1 & $S=0.4160 X+37.8$ & $189-9,434$ & .10 \\
\hline $\mathrm{Sr}(\mathrm{ppb})$ & $Y=0.021 x+0.598$ & $41.0-718$ & 1 & $*$ & * & 8 \\
\hline $\mathrm{Ba}(\mathrm{ppb})$ & $Y=0.042 x+1.145$ & $7.65-507$ & 1 & $S=0.1819 X+2.78$ & $9-377$ & 2 \\
\hline $\mathrm{Cl}$ (ppm) & $Y=0.021 x+0.866$ & $7.60-133$ & .1 & NA & NA & $\mathrm{NA}$ \\
\hline $\mathrm{F}(\mathrm{ppm})$ & $Y=0.054 x+0.017$ & $0.23-1.24$ & .1 & NA & NA & NA \\
\hline $\mathrm{SO}_{4}(\mathrm{ppm})$ & $Y=0.036 x+0.356$ & $6.06-621$ & .1 & NA & NA & NA \\
\hline
\end{tabular}




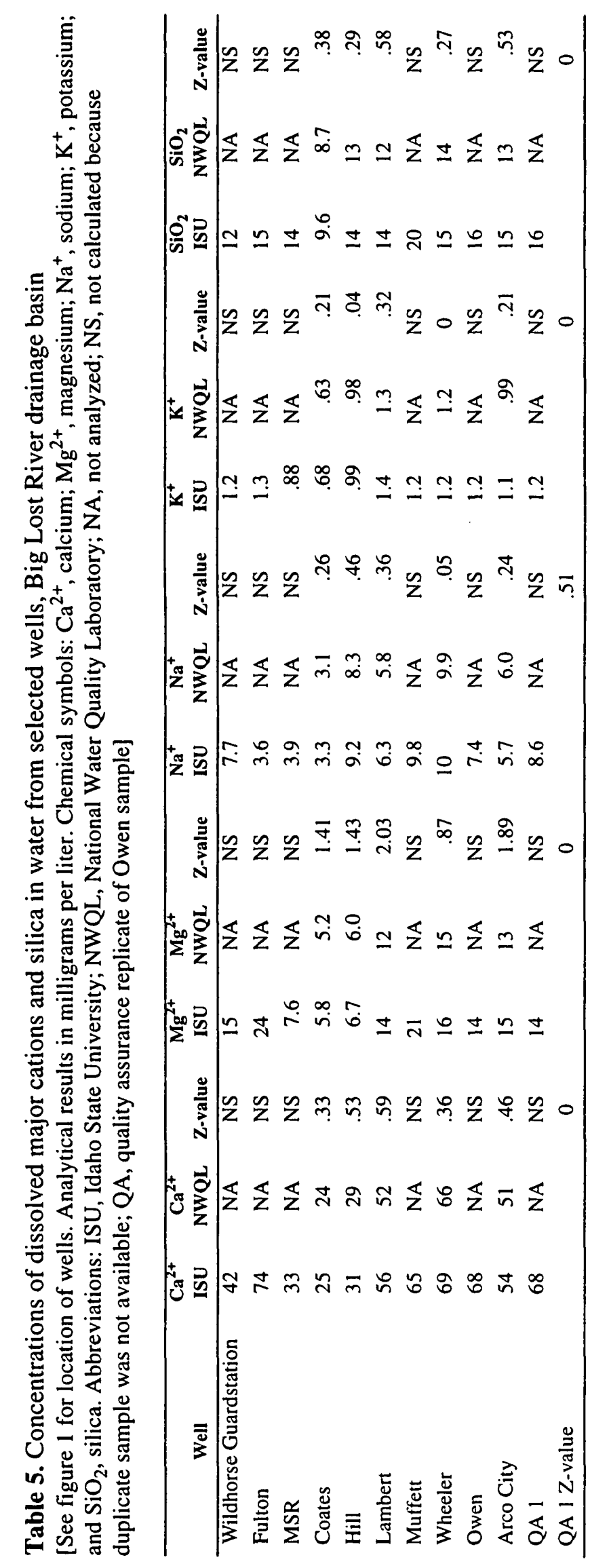


Table 6. Concentrations of dissolved major anions in water from selected wells, Big Lost River drainage basin

[See figure 1 for location of wells. Laboratory analyses were performed by the U.S. Geological Survey National Water Quality Laboratory. Analytical results in milligrams per liter. Bicarbonate data were calculated from alkalinity field measurements listed in table 3; the alkalinity (as calcium carbonate) was divided by 0.8202 . Abbreviation: QA, quality assurance replicate of Owen sample]

\begin{tabular}{|c|c|c|c|c|}
\hline Well & Chloride & Sulfate & Bicarbonate & Fluoride \\
\hline Wildhorse Guardstation & 2.6 & 17 & 193 & 0.21 \\
\hline Fulton & 9.5 & 21 & 296 & .32 \\
\hline MSR & 2.7 & 13 & 121 & .15 \\
\hline Coates & 1.6 & 12 & 89 & .18 \\
\hline Hill & 2.8 & 14 & 123 & .20 \\
\hline Lambert & 4.5 & 19 & 213 & .24 \\
\hline Muffett & 7.7 & 20 & 269 & .41 \\
\hline Wheeler & 7.5 & 26 & 251 & .18 \\
\hline Owen & 6.3 & 23 & 243 & .19 \\
\hline Arco City & 6.4 & 20 & 222 & .16 \\
\hline QA 1 & 6.3 & 23 & 243 & .19 \\
\hline QA 1 Z-value & 0 & 0 & 0 & 0 \\
\hline
\end{tabular}


Table 7. Concentrations of dissolved trace elements in water from selected wells, Big Lost River drainage basin

[See figure 1 for location of wells. Analytical results in micrograms per liter. Abbreviations: QA, quality assurance replicate of Owen sample; ISU, Idaho State University; NWQL, National Water Quality Laboratory; NA, not analyzed; NC, not calculated because uncertainty data not available; NS, not calculated because duplicate sample was unavailable. Symbols: <, less than; *, estimated concentration below the instrument detection limit. Z-value for bromide was calculated using a relative standard deviation of 15 percent (Pritt and Jones, 1989, p. 5-6)]

\begin{tabular}{|c|c|c|c|c|c|c|c|}
\hline Well & $\begin{array}{l}\text { Aluminum } \\
\text { ISU }\end{array}$ & $\begin{array}{c}\text { Aluminum } \\
\text { NWQL }\end{array}$ & Z-value & $\begin{array}{c}\text { Barium } \\
\text { ISU }\end{array}$ & $\begin{array}{l}\text { Barium } \\
\text { NWQL }\end{array}$ & Z-value & $\begin{array}{l}\text { Bromide } \\
\text { NWQL }\end{array}$ \\
\hline Wildhorse Guardstation & 5.0 & NA & NS & 112 & $\overline{N A}$ & $\overline{\mathrm{NS}}$ & 45 \\
\hline Fulton & 9.4 & NA & NS & 185 & NA & NS & 39 \\
\hline MSR & 3.7 & NA & NS & 66 & NA & NS & 13 \\
\hline Coates & 2.8 & $<10$ & NA & 43 & 39 & .43 & $<10$ \\
\hline Hill & 3.7 & $<10$ & NA & 97 & 88 & .53 & 14 \\
\hline Lambert & 7.0 & $<10$ & NA & 149 & 132 & .69 & 36 \\
\hline Muffett & 8.6 & NA & NS & 163 & NA & NS & 32 \\
\hline Wheeler & 8.6 & $<10$ & NA & 166 & 149 & .63 & 37 \\
\hline Owen & 8.0 & NA & NS & 167 & NA & NS & 50 \\
\hline Arco City & 7.0 & $<10$ & NA & 149 & 133 & .65 & 23 \\
\hline QA 1 & 8.6 & $\mathrm{NA}$ & NS & 166 & NA & NS & 45 \\
\hline QA 1 Z-value & & & .02 & & & .03 & .50 \\
\hline
\end{tabular}

\begin{tabular}{|c|c|c|c|c|c|c|c|c|c|c|c|}
\hline Well & $\begin{array}{c}\text { Chromium } \\
\text { ISU }\end{array}$ & $\begin{array}{c}\text { Chromium } \\
\text { NWQL }\end{array}$ & Z-Value & $\begin{array}{l}\text { Iron } \\
\text { ISU }\end{array}$ & $\begin{array}{c}\text { Iron } \\
\text { NWQL }\end{array}$ & \multicolumn{2}{|c|}{ Z-Value } & $\begin{array}{l}\text { Lead } \\
\text { ISU }\end{array}$ & $\begin{array}{c}\text { Lead } \\
\text { NWQL }\end{array}$ & Z-Value & $\begin{array}{ll}\text { Lithium } & \text { NWQL } \\
\text { e } & \text { N }\end{array}$ \\
\hline Wildhorse Guardstation & ${ }^{*} 15$ & NA & NS & 655 & $\overline{\mathrm{NA}}$ & $\overline{\mathrm{NS}}$ & & $* 8.1$ & $\overline{\mathrm{NA}}$ & NS & $\mathrm{NA}$ \\
\hline Fulton & *4.7 & NA & NS & $* 4.4$ & NA & NS & & *3.5 & NA & NS & NA \\
\hline MSR & $* 2.9$ & NA & NS & $* 6.3$ & NA & NS & & $*_{0}$ & NA & NS & NA \\
\hline Coates & $* 13$ & $<1$ & NA & 13 & 14 & .07 & & $* 6.1$ & $<1$ & NA & $<6$ \\
\hline Hill & $* 17$ & 1.3 & NA & $*_{0}$ & $<10$ & $\mathrm{NA}$ & & *8.4 & $<1$ & NA & $<6$ \\
\hline Lambert & 22 & $<1$ & NA & $*_{0}$ & $<10$ & NA & & *7.9 & $<1$ & NA & $<6$ \\
\hline Muffett & $* 2.1$ & NA & NS & $* 2.8$ & NA & NS & & $* 8.1$ & NA & NS & NA \\
\hline Wheeler & 19 & $<1$ & NA & $* 7.0$ & 12 & .36 & & $7.6^{*}$ & $<1$ & NA & $<6$ \\
\hline Owen & $* 12$ & NA & NS & $* 2.6$ & NA & NS & & $3.7^{*}$ & NA & NS & NA \\
\hline Arco City & *14 & 1.2 & NA & $*_{0}$ & $<10$ & NA & & $2.3^{*}$ & $<1$ & NA & $<6$ \\
\hline QA 1 & $*_{0}^{*}$ & NA & NS & $* 2.4$ & NA & NS & & $5.2^{*}$ & NA & NS & NA \\
\hline QA I Z-value & & & 1.75 & & & .01 & & & & .15 & NA \\
\hline Well & $\begin{array}{c}\text { Manganese } \\
\text { ISU }\end{array}$ & $\begin{array}{c}\text { Manganese } \\
\text { NWQL }\end{array}$ & Z-Value & $\begin{array}{c}\text { Strontium } \\
\text { ISU }\end{array}$ & $\begin{array}{r}\text { Strontil } \\
\text { NWQ }\end{array}$ & & Z-Valu & & $\begin{array}{l}\text { Zinc } \\
\text { ISU }\end{array}$ & $\begin{array}{c}\text { Zinc } \\
\text { NWQL }\end{array}$ & Z-value \\
\hline Wildhorse Guardstation & 18 & $\mathrm{NA}$ & NS & 686 & $\overline{\mathrm{NA}}$ & & NS & & 56 & NA & NS \\
\hline Fulton & $* 1.1$ & NA & NS & 357 & NA & & NS & & 28 & NA & NS \\
\hline MSR & *.41 & NA & NS & 202 & NA & & NS & & $* 7.2$ & NA & NS \\
\hline Coates & $* 1.4$ & $<3$ & NA & 161 & 153 & & $\mathrm{NC}$ & & $* 9.2$ & $<20$ & NA \\
\hline Hill & $* .25$ & $<3$ & NA & 186 & 171 & & NC & & $* 19$ & $<20$ & NA \\
\hline Lambert & $* .49$ & $<3$ & NA & 285 & 254 & & $\mathrm{NC}$ & & *17 & $<20$ & NA \\
\hline Muffett & *.67 & NA & NS & 316 & NA & & NS & & * 8.4 & NA & NS \\
\hline Wheeler & $* .71$ & $<3$ & NA & 350 & 323 & & $\mathrm{NC}$ & & *21 & $<20$ & NA \\
\hline Owen & $* .14$ & NA & NS & 322 & NA & & NS & & *14 & NA & NS \\
\hline Arco City & $* .18$ & $<3$ & NA & 275 & 253 & & $\mathrm{NC}$ & & $* 7.2$ & $<20$ & NA \\
\hline QA 1 & $* .17$ & NA & NS & 327 & NA & & NS & & *16 & NA & NS \\
\hline QA $1 \mathrm{Z}$-value & & & .02 & & & & $\mathrm{NC}$ & & & & .28 \\
\hline
\end{tabular}


Table 8. Concentrations of dissolved nutrients and dissolved organic carbon in water from selected wells, Big Lost River drainage basin

[See figure 1 for location of wells. Analytical results in milligrams per liter. Laboratory analyses were performed by the U S. Geological Survey National Water Quality Laboratory. Abbreviations: DOC, dissolved organic carbon; QA, quality assurance replicate of Owen sample. Symbol: <, less than]

\begin{tabular}{lccccc}
\hline \multicolumn{1}{c}{ Well } & $\begin{array}{c}\text { Ammonia as } \\
\text { nitrogen }\end{array}$ & $\begin{array}{c}\text { Nitrite as } \\
\text { nitrogen }\end{array}$ & $\begin{array}{c}\text { Nitrite plus } \\
\text { nitrate as } \\
\text { nitrogen }\end{array}$ & $\begin{array}{c}\text { Orthophosphate } \\
\text { as phosphorous }\end{array}$ & DOC \\
\hline Wildhorse Guardstation & 0.03 & $<0.01$ & $<0.05$ & 0.02 & 0.3 \\
Fulton & .03 & $<.01$ & 1.8 & .06 & .9 \\
MSR & $<.02$ & $<.01$ & .18 & .02 & .3 \\
Coates & .02 & $<.01$ & .072 & .02 & .5 \\
Hill & $<.02$ & $<.01$ & .23 & .02 & .3 \\
Lambert & $<.02$ & $<.01$ & .29 & .04 & .7 \\
Muffett & .02 & $<.01$ & .79 & .04 & .8 \\
Wheeler & .022 & $<.01$ & 1.6 & .02 & .4 \\
Owen & $<.02$ & $<.01$ & 2.1 & .03 & .6 \\
Arco City & $<.02$ & $<.01$ & .71 & .02 & $<.1$ \\
QA 1 & $<.02$ & $<.01$ & 2.1 & .03 & .6 \\
QA 1 Z-value & 0 & 0 & 0 & 0 & 0 \\
\hline
\end{tabular}

Table 9. Concentrations of tritium, gross alpha- and gross beta-particle radioactivity, and selected stable isotopes in water from selected wells, Big Lost River drainage basin

[See figure 1 for location of wells. Laboratory analyses were performed by the U.S. Geological Survey National Water Quality Laboratory. Analytical results and uncertainties-for example, $35.2 \pm 25.6$ in indicated units.

Analytical uncertainties are reported as $2 s$ except for $\delta^{2} \mathrm{H}, \delta^{18} \mathrm{O}$, and $\delta^{13} \mathrm{C}$, which are reported as 1s. Units: pCi/L, picocuries per liter; permil, parts per thousand relative to a standard. Abbreviation: QA, quality assurance replicate of Owen sample. Symbols: ${ }^{230} \mathrm{Th}$, thorium-230; ${ }^{137} \mathrm{Cs}$, cesium-137; $\delta^{2} \mathrm{H}$, delta notation for stable hydrogen isotope ratios; $\delta^{18} \mathrm{O}$, delta notation for stable oxygen isotope ratios; $\delta^{13} \mathrm{C}$, delta notation for stable carbon isotope ratios; \pm , plus or minus]

\begin{tabular}{lcccccc}
\hline \multicolumn{1}{c}{ Well } & $\begin{array}{c}\text { Tritium } \\
\text { (pCiL) }\end{array}$ & $\begin{array}{c}\text { alpha(pCi/L } \\
\left.\text { as }{ }^{230} \mathbf{T h}\right)\end{array}$ & $\begin{array}{c}\text { beta }(\mathbf{p C i / L} \\
\left.\text { a }^{137} \mathbf{C s}\right)\end{array}$ & $\begin{array}{c}\delta^{2} \mathbf{H} \pm 1.5 \\
\text { permil }\end{array}$ & $\begin{array}{c}\delta^{18} \mathbf{O} \pm \mathbf{1 . 5} \\
\text { permil }\end{array}$ & $\begin{array}{c}\delta^{15} \mathbf{C} \pm \mathbf{0 . 3} \\
\text { permil }\end{array}$ \\
\hline Wildhorse Guardstation & $32 \pm 25.6$ & $1.01 \pm 2.5$ & $1.50 \pm 1.25$ & -141.7 & -18.37 & -7.88 \\
Fulton & $54.4 \pm 26.8$ & $4.10 \pm 3.18$ & $2.58 \pm 1.92$ & -130.7 & -17.28 & -10.79 \\
MSR & $83.2 \pm 25.6$ & $1.53 \pm 2.49$ & $2.52 \pm 1.14$ & -136.7 & -18.12 & -9.01 \\
Coates & $19.2 \pm 25.6$ & $0.92 \pm 2.28$ & $2.79 \pm 1.07$ & -134.7 & -17.60 & -7.9 \\
Hill & $25.6 \pm 25.6$ & $1.37 \pm 2.7$ & $2.81 \pm 1.13$ & -134.0 & -17.72 & -9.03 \\
Lambert & $3.2 \pm 25.6$ & $4.96 \pm 3.28$ & $2.78 \pm 1.57$ & -135.1 & -17.60 & -10.88 \\
Muffett & $57.6 \pm 25.6$ & $2.15 \pm 3.07$ & $3.84 \pm 1.91$ & -131.9 & -17.19 & -12 \\
Wheeler & $19.2 \pm 25.6$ & $2.49 \pm 3.14$ & $3.41 \pm 1.88$ & -132.6 & -17.32 & -11.47 \\
Owen & $0.0 \pm 25.6$ & $2.79 \pm 2.84$ & $2.17 \pm 1.83$ & -132.0 & -17.32 & -11.84 \\
Arco City & $35.2 \pm 25.6$ & $2.51 \pm 2.19$ & $5.23 \pm 1.18$ & -135.0 & -17.73 & -10.33 \\
QA 1 & $38.4 \pm 25.6$ & $3.10 \pm 2.91$ & $3.12 \pm 1.89$ & -133.2 & -17.33 & -11.73 \\
QA 1 Z-value & 2.12 & .15 & .72 & .57 & .00 & .26 \\
\hline
\end{tabular}


Table 10. Mineral/water thermodynamic saturation indices for water from selected sites, Big Lost River drainage basin

[See figure 1 for location of sites. Saturation indices are log IAP/K (ion activity product/equilibrium constant); positive values indicate saturation, negative values indicate undersaturation, and zero \pm 0.1 values indicate equilibrium. Abbreviation: BLR, Big Lost River]

\begin{tabular}{|c|c|c|c|}
\hline Site identifier & Calcite & Dolomite & Anhydrite \\
\hline Wildhorse Guardstation & 0.216 & 0.059 & -2.731 \\
\hline Fulton & .093 & -.219 & -2.473 \\
\hline MSR & -.108 & -.785 & -2.884 \\
\hline Coates & -1.096 & -2.770 & -3.028 \\
\hline Hill & -.108 & -.781 & -2.880 \\
\hline Lambert & .003 & -.503 & -2.585 \\
\hline Muffett & -.068 & -.504 & -2.547 \\
\hline Wheeler & .117 & -.286 & -2.403 \\
\hline Owen & .138 & -.289 & -2.437 \\
\hline Arco City & .165 & -.133 & -2.579 \\
\hline BLR near Mackay (Bartholomay, 1990) & .691 & .851 & -2.608 \\
\hline BLR near Mackay (Busenberg and others, 2000) & -.094 & -.663 & -2.991 \\
\hline BLR at Howell Ranch near Chilly (Crosthwaite and others, 1970) & -.799 & -2.193 & -3.189 \\
\hline
\end{tabular}


Table 11. Thermodynamically possible models obtained with NETPATH

[See figure 1 for location of sites. Units are millimoles per kilogram of water. BLR (1990) indicates Big Lost River near Mackay reported by Bartholomay (1990); BLR (2000) indicates Big Lost River near Mackay reported by Busenberg and others (2000); \%, percent of water from each site to obtain results; -, indicates precipitation; others dissolution; $\mathrm{nr}$, near; $\mathrm{CO}_{2}$, carbon dioxide]

\begin{tabular}{|c|c|c|c|c|c|}
\hline \multicolumn{6}{|c|}{ NON MIXING MODELS WITH GYPSUM } \\
\hline Initial & Final & Calcite & Dolomite & Gypsum & $\mathrm{CO}_{2}$ gas \\
\hline Coates & Hill & 0.09602 & 0.03737 & 0.02561 & 0.16190 \\
\hline Coates & Muffett & .29808 & .6143 & .08402 & 1.67384 \\
\hline Hill & Lambert & .27526 & .29653 & .04902 & .81460 \\
\hline Lambert & Muffett & -.07320 & .28040 & .00939 & .69734 \\
\hline \multicolumn{6}{|c|}{ NON MIXING MODELS WITHOUT GYPSUM } \\
\hline Initial & Final & Calcite & Dolomite & $\mathrm{CO}_{2}$ gas & \\
\hline Fulton & MSR & -1.02605 & & -2.27463 & \\
\hline Coates & Hill & .12163 & 0.03737 & .13629 & \\
\hline $\begin{array}{l}\text { Wildhorse } \\
\text { Guardstation }\end{array}$ & Coates & -.04088 & -.39588 & -.65088 & \\
\hline Hill & Lambert & .32428 & .29653 & .76558 & \\
\hline Lambert & Muffett & -.06381 & .28040 & .68795 & \\
\hline Muffett & Wheeler & .09826 & & -.63194 & \\
\hline Wheeler & Owen & -.02521 & & -.13273 & \\
\hline Owen & Arco City & -.35763 & .02832 & -.18279 & \\
\hline
\end{tabular}


Table 11. Thermodynamically possible models obtained with NETPATH-Continued.

\begin{tabular}{|c|c|c|c|c|c|c|c|c|}
\hline & & & MIXING & $\overline{D E L S}$ & & & & \\
\hline & Initial 1 & Initial 2 & Final & Calcite & Dolomite & Gypsum & $\mathrm{CO}_{2}$ gas & Exchange \\
\hline & Fulton & Coates & Hill & & & & & \\
\hline$\%$ & 4.917 & 95.083 & & 0.09860 & & & 0.05735 & \\
\hline$\%$ & 4.917 & 95.083 & & .07786 & & 0.02073 & .07809 & \\
\hline & MSR & Coates & Hill & & & & & \\
\hline$\%$ & 51.516 & 48.484 & & .05479 & & & .12701 & \\
\hline$\%$ & 51.516 & 48.484 & & .03734 & & .01745 & .14446 & \\
\hline$\%$ & 51.516 & 48.484 & & .18179 & & .01745 & & .01745 \\
\hline & Wildhorse Guardstation & Fulton & MSR & & & & & \\
\hline$\%$ & 79.212 & 20.788 & & & -0.39903 & & -.83125 & \\
\hline & Wildhorse Guardstation & BLR nr Howell Ranch & MSR & & & & & \\
\hline$\%$ & 36.0 & 64.0 & & .12829 & -.00632 & & & \\
\hline$\%$ & 34.7 & 65.3 & & .12908 & & & .01263 & \\
\hline & Hill & Lambert & Muffett & & & & & \\
\hline$\%$ & 19.677 & 80.323 & & & .33875 & & .83860 & \\
\hline$\%$ & 26.593 & 73.407 & & & .35926 & .02243 & .91397 & \\
\hline & Lambert & Muffett & Wheeler & & & & & \\
\hline$\%$ & 69.608 & 30.392 & & .24902 & & & .04211 & \\
\hline$\%$ & 69.608 & 30.392 & & .18182 & & .06721 & .10931 & \\
\hline & Muffett & BLR (1990) & Wheeler & & & & & \\
\hline$\%$ & 72.733 & 27.267 & & .26824 & -.08585 & .05696 & & \\
\hline & Muffett & BLR (2000) & Wheeler & & & & & \\
\hline$\%$ & 67.2 & 32.8 & & .33161 & & .08493 & .10869 & \\
\hline & Wheeler & Owen & Arco City & & & & & \\
\hline$\%$ & 39.503 & 60.497 & & -.33927 & & & -.20690 & \\
\hline & Owen & BLR (2000) & Arco City & & & & & \\
\hline$\%$ & 66.2 & 33.8 & & -.11579 & .13912 & & .12325 & \\
\hline$\%$ & 46.9 & 53.1 & & & .20214 & .02176 & .31909 & \\
\hline
\end{tabular}


Table 12. Models with thermodynamic impossibilities obtained with NETPATH

[See figure 1 for location of sites. Units are millimoles per kilogram of water. BLR (1990) indicates Big Lost River near Mackay reported by Bartholomay (1990); BLR (2000) indicates Big Lost River near Mackay reported by Busenberg and others (2000); \%, percent of water from each site to obtain results; -, indicates precipitation; others dissolution; $\mathrm{nr}$, near; $\mathrm{CO}_{2}$, carbon dioxide; $\mathrm{K}$-spar, potassium feldspar; $\mathrm{NaCl}$, sodium chloride; Plag AN45, plagioclase feldspar consisting of 45 percent anorthite]

\begin{tabular}{|c|c|c|c|c|c|c|c|c|c|}
\hline & \multicolumn{9}{|c|}{ MIXING MODELS } \\
\hline & Initial 1 & Initial 2 & Initial 3 & Final & Calcite & Dolomite & Gypsum & $\mathrm{CO}_{2}$ gas & Exchange \\
\hline & $\begin{array}{l}\text { Wildhorse } \\
\text { Guardstation }\end{array}$ & Fulton & MSR & Coates & $\begin{array}{l}\text { No models } \\
\text { found. }\end{array}$ & & & & \\
\hline & Coates & $\begin{array}{l}\text { BLR nr } \\
\text { Howell } \\
\text { Ranch }\end{array}$ & & Hill & $\begin{array}{l}\text { No models } \\
\text { found. }\end{array}$ & & & & \\
\hline & Fulton & Coates & & Hill & & & & & \\
\hline$\%$ & 8.490 & 91.510 & & & 0.08186 & -0.02715 & & & \\
\hline$\%$ & 25.968 & 74.032 & & & & -.15998 & & -0.28056 & \\
\hline$\%$ & 25.824 & 74.176 & & & .00067 & -.15888 & & -.27825 & \\
\hline$\%$ & 9.499 & 90.501 & & & .06095 & -.03482 & 0.01619 & & \\
\hline$\%$ & 26.007 & 73.993 & & & & -.16027 & -.00018 & -.28136 & \\
\hline & Fulton & MSR & & Hill & & & & & \\
\hline$\%$ & 7.665 & 92.335 & & & -.03746 & -.08786 & .00338 & & \\
\hline & MSR & Coates & & Hill & & & & & \\
\hline$\%$ & 93.742 & 6.258 & & & & -.03063 & & .11940 & \\
\hline$\%$ & 84.295 & 15.705 & & & & -.02378 & .01226 & .13336 & \\
\hline & Coates & BLR (1990) & & Hill & & & & & \\
\hline$\%$ & 45.035 & 54.965 & & & .00368 & -.07990 & -.02806 & & \\
\hline & $\begin{array}{l}\text { Wildhorse } \\
\text { Guardstation }\end{array}$ & Fulton & & MSR & & & & & \\
\hline$\%$ & 66.894 & 33.106 & & & & -.44387 & -.05266 & -1.00147 & \\
\hline & $\begin{array}{l}\text { Wildhorse } \\
\text { Guardstation }\end{array}$ & $\begin{array}{l}\text { BLR nr } \\
\text { Howell } \\
\text { Ranch }\end{array}$ & & MSR & & & & & \\
\hline & 57.8 & 42.2 & & & -.06626 & & & & .13212 \\
\hline & 13.8 & 86.2 & & & & .0757 & & & .2888 \\
\hline & Lambert & Muffett & & Wheeler & & & & & \\
\hline & 63.487 & 36.513 & & & .25293 & -.01716 & & & \\
\hline & 53.932 & 46.068 & & & .19329 & -.04395 & .06573 & & \\
\hline & Muffett & Wheeler & & Owen & & & & & \\
\hline & 35.355 & 64.645 & & & .15023 & -.14070 & & -.21546 & \\
\hline & Muffett & BLR (2000) & & Wheeler & & & & & \\
\hline & 74.5 & 25.5 & & & .30945 & -.04376 & .07949 & & \\
\hline & Wheeler & BLR (1990) & & Owen & & & & & \\
\hline & 91.777 & 8.223 & & & .09777 & -.05477 & -.01758 & & \\
\hline & Owen & BLR (1990) & & Arco City & & & & & \\
\hline & 79.489 & 20.511 & & & -.26321 & .05582 & -.03301 & & -.03220 \\
\hline & 75.991 & 24.009 & & & -.21594 & .06051 & -.03211 & & \\
\hline & Owen & BLR (2000) & & Arco City & & & & & \\
\hline & 78.3 & 21.7 & & & -.18867 & .09945 & -.0137 & & \\
\hline
\end{tabular}


Table 12. Models with thermodynamic impossibilities obtained with NETPATH-Continued

\begin{tabular}{|c|c|c|c|c|c|}
\hline \multicolumn{6}{|c|}{ NON MIXING MODELS } \\
\hline Initial & Final & Calcite & Dolomite & Gypsum & $\mathrm{CO}_{2}$ gas \\
\hline Fulton & MSR & -0.25530 & -0.68742 & -0.08333 & -1.67054 \\
\hline MSR & Coates & -.20229 & & & -.09056 \\
\hline MSR & Coates & -.11391 & -.07254 & -.01584 & -.03386 \\
\hline Fulton & MSR & -.33863 & -.68742 & & -1.58721 \\
\hline MSR & Coates & -.12975 & -.07254 & & -.01802 \\
\hline MSR & Hill & -.01789 & -.03517 & .00977 & .12804 \\
\hline Wildhorse Guardstation & MSR & .0887 & -.32334 & & -.63286 \\
\hline Wildhorse Guardstation & Coates & .01244 & -.39588 & -.05332 & -.70420 \\
\hline Wildhorse Guardstation & Hill & .10846 & -.35851 & -.02771 & -.54230 \\
\hline Lambert & Muffett & .21659 & & & .96835 \\
\hline Muffett & Wheeler & .29344 & -.19518 & & -.43676 \\
\hline Muffett & Arco City & -.01867 & -.23855 & .00096 & -.67963 \\
\hline Lambert & Wheeler & .15957 & .08522 & .07006 & .32125 \\
\hline Lambert & Owen & .22750 & .01353 & .04861 & .23876 \\
\hline Muffett & Wheeler & .23277 & -.19518 & .06067 & -.37609 \\
\hline Wheeler & Owen & .06793 & -.07169 & -.02145 & -.08249 \\
\hline Owen & Arco City & -.31937 & .02832 & -.03826 & -.22105 \\
\hline Wheeler & Owen & .04648 & -.07169 & & -.06104 \\
\hline Wheeler & Arco City & -.25144 & -.04337 & -.05971 & -.30354 \\
\hline & & COMPREHENSIVE $\mathbf{N}$ & V MIXING MODELS & & \\
\hline Initial & Calcite & Dolomite & $\mathrm{CO}_{2}$ gas & K-spar & Plag AN45 \\
\hline Lambert & -0.14784 & 0.30429 & -0.09557 & 0.05284 & 0.09031 \\
\hline
\end{tabular}

